\title{
Výsledky revízneho výskumu mladopaleolitickej lokality v Moravanoch nad Váhom-Podkovici (Slovenská republika)
}

\author{
Revision excavations of the Upper Paleolithic site in Moravany \\ nad Váhom-Podkovica (Slovak Republic)
}

- Bibiána Hromadová*, Adrián Nemergut, Laurent Klaric, Martina Moravcová Ábelová, Martin Vlačiky -

\section{KEYWORDS}

Upper Paleolithic - Gravettian - Slovakia - Moravany nad Váhom-Podkovica - revision excavation - stratigraphy - shouldered points - dating

\section{ABSTRACT}

The Paleolithic site in Moravany nad Váhom-Podkovica is located in the north-eastern part of the Moravian settlement area and is among the most famous Upper Paleolithic sites in Slovakia. It is a key site of the Willendorf-Kostenkian and the so-called Shouldered Point Horizon in Central Europe. Despite decades of research, interest during the previous century and the numerous existing - but lost or scattered - collections, the context of the finds and the characteristics of the cultural layers remain almost unknown. Modern research methods and the absence of the relevant chrono-cultural classification of the assemblages led to reopening the field research. This research aims to review and reassess the results of older excavations, to identify the exact location of the site and the conditions of the preservation of the layers. The goal is also to collect new material suitable for multidisciplinary analysis and dating as most of the old collections have been scattered. The new excavations conducted at the site in 2016 and 2019 brought interesting results, such as a preserved anthropogenic layer with an evident structure filled with datable material. This article presents the methodology and the results of this work with a focus on the first mineralogical evaluations, the analysis of faunal remains and an overview of the stone industry.

\footnotetext{
* Corresponding author - E-mail address: bibiana.hromadova@gmail.com https://doi.org/10.47382/pv0621-07

Received 18 February 2021; received in revised form 6 May 2021. Available online 30 June 2021.
}

Copyright (c) 2021 Czech Acad Sci, Inst Archaeology Brno, and the authors. This is an open access article under the CC BY-NC-ND 4.0 license (https://creativecommons.org/licenses/by-nc-nd/4.0/).

Competing interests: The authors have declared that no competing interests exist.

\section{1. Úvod}

Komplex paleolitických sídlisk medzi Modrovkou a Sokolovcami na západnom Slovensku, s centrom v Moravanoch nad Váhom pri Pieštanoch, je dobre známy z odbornej literatúry a už takmer celé storočie pritahuje pozornost̉ vedcov aj laických nadšencov. Sídliskový areál, zahŕňajúci viac ako 50 samostatných sídelných celkov, sa koncentruje na prevažne $12 \mathrm{~km}$ úseku lavého brehu rieky Váh. Bol sformovaný v relatívne krátkom časovom horizonte, a to od počiatku staršej fázy mladého paleolitu až do neskorej fázy tzv. Last Glacial Maximum (d’alej LGM) (napr. Ambrož et al. 1952; Bárta 1970; Hromada 1998; Kozłowski ed. 1998, Kozłowski ed. 2000; Nemergut 2010; Nerudová, Valoch 2009). Objektívne o ňom možno hovorit ako o najperspektívnejšom regióne pre výskum paleolitu na Slovensku s európskym významom.

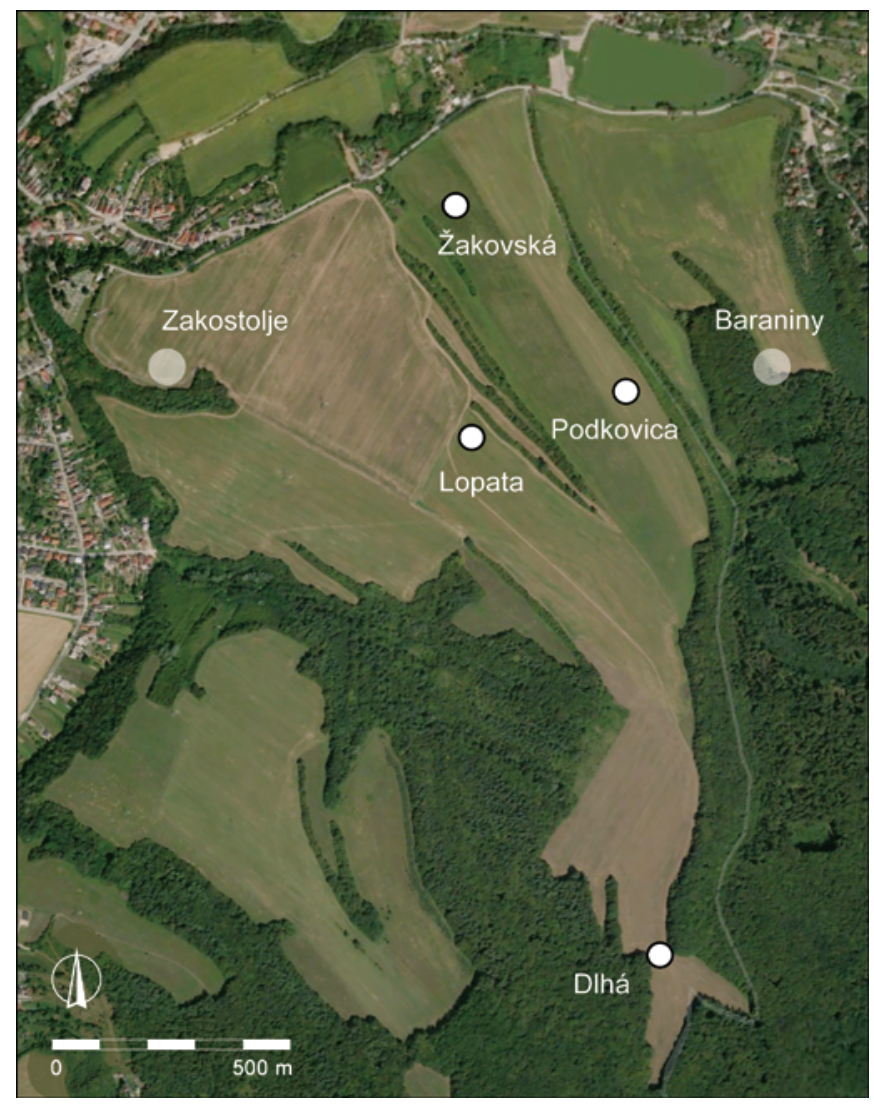

Obr. 1. Moravany nad Váhom s vyznačením najbližších okolitých lokalít. Vyhotovila B. Hromadová.

Fig. 1. Moravany nad Váhom area with the closest sites. Graphics by B. Hromadová. 
Jednou z najznámejších lokalít v tomto areáli je nepochybne gravettienska stanica v polohe Podkovica (obr. 1). Známa sa stala vd’aka nálezu moravianskej venuše z mamutoviny a nálezom hrotov s vrubom, ktoré sú typickým diagnostickým prvkom mladogravettienskeho materiálu a dôležitým elementom $\mathrm{v}$ diskusii ohl'adom horizontu hrotov s vrubom a definícii willendorf-kostenkienu (Klaric, Hromadová 2016). Napriek prítomnosti takýchto významných nálezov, vrátane početnej kolekcie hrotov s vrubom, väčšina $\mathrm{z}$ nich nebola nájdená $\mathrm{v}$ kontexte kultúrnej vrstvy. Získané boli povrchovým zberom, bez podrobnej dokumentácie nálezových okolností a ich pôvod tak ostáva problematický (Hromada 1998, 154-155; Kaminská 2014, 228; Klaric, Hromadová 2016). Nejasnou zostáva aj štruktúra osídlenia a charakter kultúrnych vrstiev, nájdených a čiastkovo publikovaných F. Prošekom v 40. rokoch 20. storočia (Ambrož et al. 1952).

Najvážnejším dôvodom, prečo boli v Podkovici v roku 2016 obnovené terénne práce, bola nutnost’ potvrdit diagnostické prvky archeologickej kolekcie v kontexte moderne preskúmanej archeologickej vrstvy. Ciel'om týchto prác nebolo len hl'adanie neporušených vrstiev, ale v prvom rade konsolidácia a interpretácia rozsiahlej terénnej dokumentácie, ktorú po sebe zanechali predošlí bádatelia. Hoci výskum na tejto lokalite patril k najväčším F. Prošeka, jeho skúsený prírodovedno-archeologický tým bol vystavený neustálym prekážkam. Jednou z najpálčivejších bola identifikácia kultúrnej vrstvy v kontexte redeponovaných a silne poškodených sedimentov z obdobia vrcholu LGM, v ktorých sa pravdepodobne nachádzali antropogénne vrstvy (Ambrož et al. 1952). Podobný problém sa vyskytol aj v polohe Lopata II, ležiacej na vedl'ajšom sprašovom chrbte, v podobnom kontexte vrstiev z obdobia záveru MIS2 (t.j. morský izotopový stupeň 2, ang. marine isotope stage 2; d'alej MIS2; Pawlikowski et al. 1998).

Archeologický výskum v roku 2019 potvrdil nálezy mladopaleolitického materiálu a objektu priamo vo vrstvách. V súlade s prioritami revízneho výskumu bol kladený dôraz na nutné kontextuálne vyhodnotenie materiálu a analýzu terénnej situácie. Predbežne získané výsledky otvorili diskusiu o ich interpretácii, spôsobe výskumu a chronologickom zaradení na základe datovania dostupných materiálov. Práve datovacie metódy sú vzhl’adom na stav vrstiev a zlú zachovalost̉ datovatel'ného organického materiálu značne obmedzené. Aj z týchto dôvodov je počet spracovaných vzoriek z lokalít v moravianskom sídliskovom areáli, vrátane Podkovice, stále limitovaný. Situáciu čiastočne vylepšil nález zahĺbeného objektu v predpokladanej vrstve v Podkovici v roku 2019, z ktorého boli odobrané a poslané na analýzu dve vzorky prepálených kostí, pravdepodobne z neporušeného kontextu. Ciel'om budúcich výskumov bude nielen samotná analýza vrstiev, zber archeologického materiálu, ale aj upresnenie mikrostratigrafie a geochronologické porovnanie vrstiev s okolitými lokalitami, vrátane geologických profilov vo Vel'kom a Hlbokom Jarku.

\section{História archeologického výskumu}

Prvé systematické povrchové zbery v polohe Podkovica sú známe z 30. rokov 20. storočia a boli realizované V. Vlkom (Hromada 1998, 154; Klaric, Hromadová 2016). V období pred a počas 2. svetovej vojny viedol tieto práce nemecký archeológ L. Zotz, toho času profesor nemeckej Karlovej univerzity v Prahe. Rozsah jeho výskumu, žial', nepoznáme, nakol'ko bola výskumná dokumentácia na konci druhej svetovej vojny odvezená do Nemecka a v súčasnosti je jej časť súčastou tzv. Alexandrijského archívu (Hromada 1997, 47; 1998, 154; Nerudová, Valoch 2009, 10-11; Zotz 1968; Zotz, Vlk 1939). Na práce L. Zotza v okolí Moravian nad Váhom nadviazal v rokoch 1946-1947 K. Absolon (Hromada 1998, 154; Nerudová, Valoch 2009), ktorý významne prispel ku konsolidácii časti zbierok po L. Zotzovi z Moravian.
Tie sa neskôr stali súčastou tzv. Absolonovej zbierky (Nerudová, Valoch 2009). Materiál je uskladnený v Balneologickom múzeu Slovenského národného múzea (d’alej BM SNM) v Pieštanoch (oficiálny dar K. Absolona múzeu) a v oddelení dokumentácie na Archeologickom ústave Slovenskej akadémie vied (d’alej AÚ SAV) časť vypožičaná J. Bártom od K. Absolona, typologicky patriaca k materiálu darovanému BM SNM. V zbierke, bohužial', nie je možné rozlíšit nálezy z jednotlivých lokalít, ked’že K. Absolon v rámci teórie o vel’kej „diluviálnej stanici“ v Moravanoch zmiešal podl’a všetkého dostupné nálezy dohromady. K d’alším Zotzovým nálezom z Karlovej univerzity sa dostal v rokoch 1947-1948 mladý vedecký pracovník Archeologického ústavu v Prahe, F. Prošek. V roku 1948 roztriedil nálezy podl'a lokalít, skatalogizoval ich (Nerudová, Valoch 2009) a neskôr odovzdal Štátnemu archeologickému ústavu v Turčianskom Sv. Martine (Prošek 1949). Nálezy z Podkovice dostali prírastkové číslo 4/48 a v súčasnosti zahŕňajú aj okolo 87 artefaktov zo sondy L. Zotza (Klaric, Hromadová 2016). Prvé terénne prieskumy F. Prošeka boli zamerané práve na polohu Podkovica, kde predpokladal neporušenú kultúrnu vrstvu. Z prác F. Prošeka vyplýva, že L. Zotz, spolu s V. Vlkom, otvorili v polohe Podkovica ešte v roku 1937 sondu (pravdepodobne $6 \times 1 \mathrm{~m}$ ). Pravdepodobne sa mu nepodarilo nájste kultúrnu vrstvu. Napriek deklarovanému výskumu a rozsiahlym terénnym prácam K. Absolona v okolí Moravian nad Váhom, F. Prošek jeho terénne aktivity v polohe Podkovica spochybnil (Ambrož et al. 1952, 122; Prošek 1949). V auguste 1949 realizoval F. Prošek so svojím prírodovedným tímom rozsiahle výskumy na sprašovom poli v polohe Podkovica, v závere parcely č. 1098 (Prošek 1949).

Celkovo F. Prošek s kolegami preskúmal v Podkovici niekol'ko rozsiahlych plôch s rozlohou asi $300 \mathrm{~m}^{2}$ (obr. 2; Prošek 1949). Výskumu sa zúčastnili okrem F. Prošeka aj prírodovedci V. Ložek (malakológia, paleoklimatológia, paleopedológia), Z. Hokr (paleozoológia), V. Ambrož (petrografia) a paleobotaniku spracovala L. Slavíková-Veselá (Ambrož et al. 1952). Hlavným ciel’om výskumu v roku 1949 bol zber paleopedologických údajov, ktoré mali vysvetlit pôvod sprašových hlín a niektoré stratigrafické otázky, ako aj spôsob uloženia kultúrnych vrstiev (Ambrož et al. 1952; Prošek 1953). V tomto kontexte sa F. Prošek snažil zistit primárnu polohu lokality. Rozsiahle odkryvy nepriniesli všetky očakávané výsledky a F. Prošek sa so svojimi spolupracovníkmi k neporušenej kultúrnej vrstve nedostali. Ani prítomnost’ vyše 447 artefaktov v rôznych častiach skúmaných plôch, vzhl'adom na rozsiahlu eróziu vrstiev v strednej časti sprašového chrbta, nedovolila F. Prošekovi označit nálezy ako in situ (Ambrož et al. 1952, 87). Obrovský význam pre štúdium lokality mali prírodovedné analýzy, analýza spraší a superpozície vrstiev. Získané údaje výrazne upresnili sedimentogenézu spraší v skúmanej polohe a zaradili archeologický materiál do presnejšieho geologického kontextu v rámci aktuálnych dobových teórií o chronológii paleolitických kultúr. Nálezy a dokumentácia boli publikované čiastočne (Ambrož et al. 1952), avšak donedávna bol materiál považovaný za stratený (Hromada 1997, 91; 1998, 155).

Po predčasnej smrti F. Prošeka sa dostal k nálezom J. Bárta, ktorý získaný materiál nikdy nezverejnil a o jeho vlastníctve nebolo nič známe. V roku 1959 sa podarilo J. Bártovi získat’ od nemeckých kolegov sošku venuše, ktorá by mala pochádzat práve z polohy Podkovica (Bárta 1965; 1970; Zotz 1968).

V 90. rokoch 20. storočia realizoval kontrolnú sondu na predmetnej lokalite aj J. Hromada v spolupráci s pol’skými kolegami (Hromada 1998, 154). Ciel'om výskumu bolo overenie stratigrafickej situácie, avšak výsledky M. Pawlikowského neboli nikdy zvlášt publikované, ani zjednotené s údajmi F. Prošeka (Hromada 1998, 154; Pawlikowski et al. 1998). 
Na lokalite Podkovica sú artefakty zbierané aj v súčasnosti, a to predovšetkým miestnymi zberatel'mi v rámci ilegálnych zberov. V priebehu rokov 2008-2015 sme navštívili viacero polôh s nálezmi kamenných artefaktov, ktoré sme následne geodeticky zamerali prostredníctvom GPS (Kaminská et al. 2011; Žaár et al. 2016; 2015). Každá overená poloha prináša desiatky artefaktov ročne. Ich predpokladaný počet však môže byt̉ mnohonásobne vyšší.

\section{Ciele a metodika súčasného výskumu}

Paleolitické lokality v okolí Moravian ležia prevažne v sprašových sedimentoch. Sprašové komplexy do hrúbky až 30 metrov pokrývajú spolu s kvartérnymi deluviálno-eluviálnymi sedimentami (hlinito-kamenitými sutinami) povrch mezozoických sedimentov (ku geológii regiónu napr. Ivanička ed. 2007; Ivanička, Kohút red. 2011). Spraše v okolí Moravian vznikali v obdobiach sucha a v období stúpajúcej vlhkosti. Krajina sa v čase osídlenia

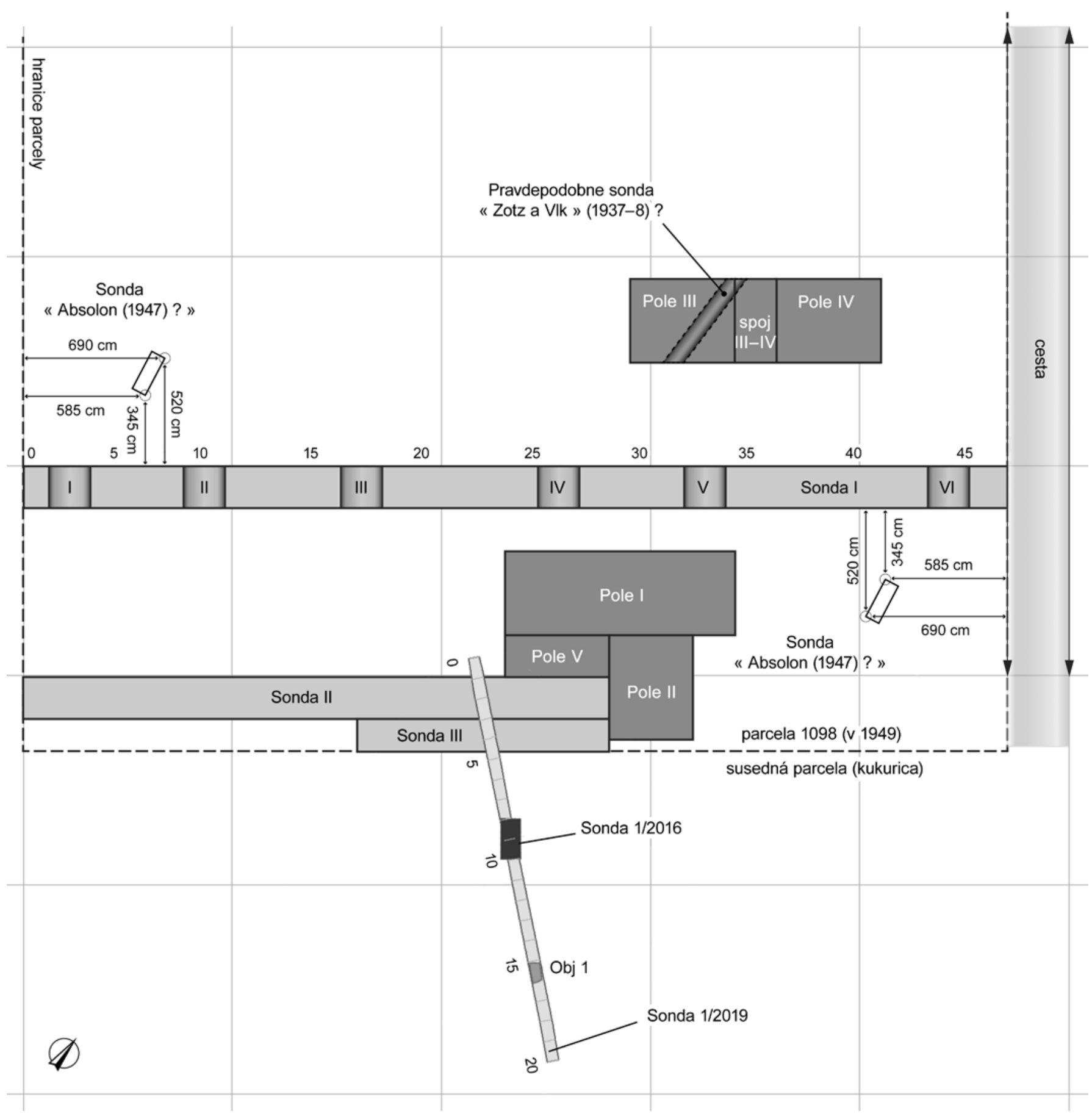

Obr. 2. Rozmiestnenie sond v polohe Podkovica (upravené podl’a dokumentácie F. Prošeka) s vyznačením orientácie sondy 1/2019. Vyhotovili L. Klaric, B. Hromadová. Fig. 2. Localisation of field survey activities at Podkovica (modified according to the documentation of F. Prošek) with localisation of trench 1/2019. Graphics by L. Klaric, B. Hromadová. 


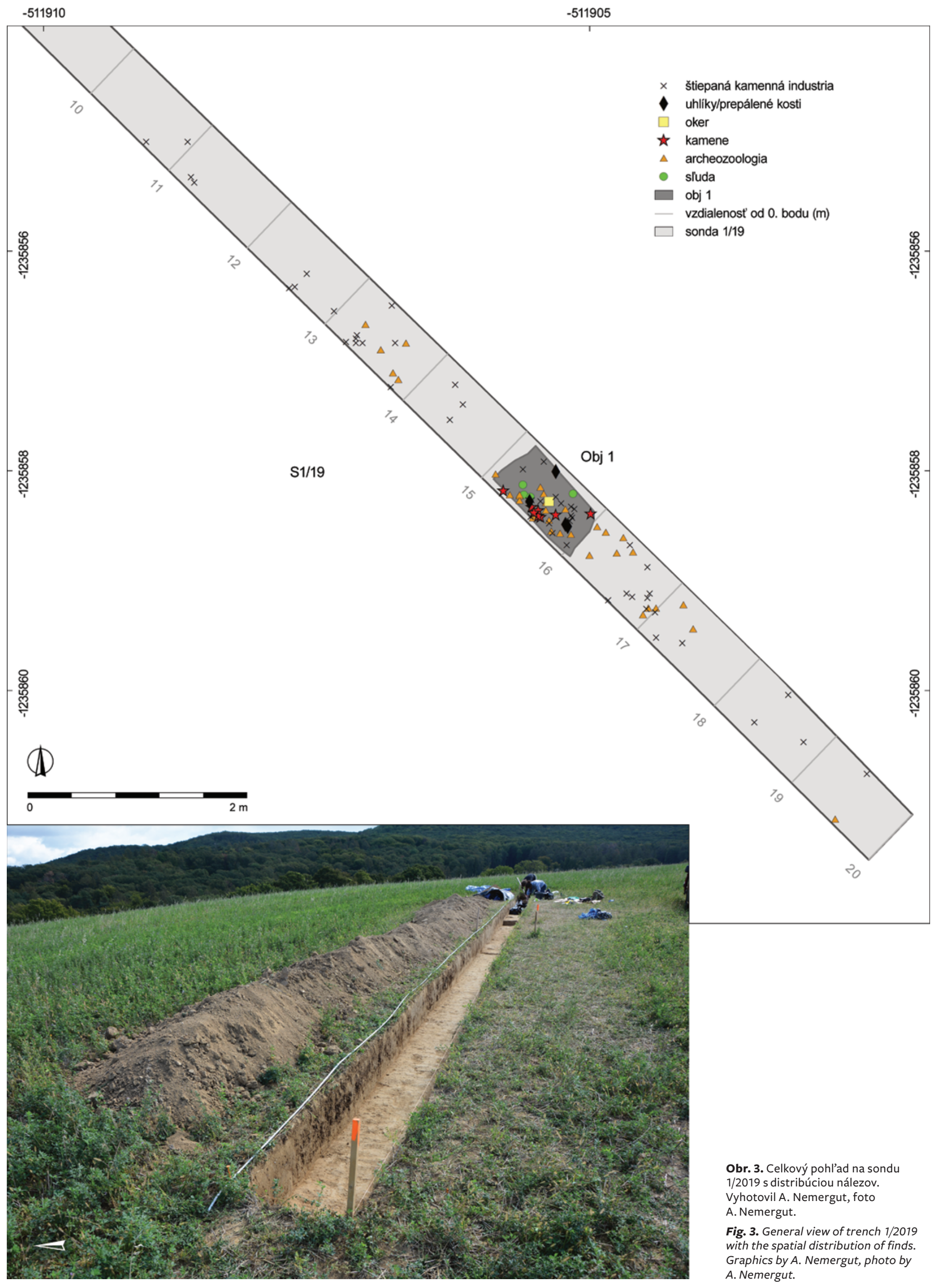


lokalít nachádzala v tzv. periglaciálnom pásme, kde v sedimentoch aktívne prebiehali kryopedologické alebo periglaciálne javy, spojené s rozsiahlou soliflukciou. Jedným z dôsledkov studenej arktickej klímy bola aj povrchová vrstva permafrostu, na lokalitách čiastkovo nájdená v podobe rôznych generácií mrazových klinov (Pawlikowski et al. 1998). Predpokladá sa, že aj v okolí Moravian dosahovala v období posledného glaciálu mocnost niekol'kých metrov. V teplejších obdobiach interštadiálov, ale aj počas subpolárneho leta sa povrchová vrstva permafrostu do istej híbky roztápala a roztopená masa skízavala po hlbšie ležiacich zamrznutých častiach. S ňou mohli byṫ premiestňované aj v nej uložené zvyšky táborísk. Rôzne posuvy a poklesy pôdnych hmôt majú vážny dopad na stav lokalít, napríklad v podobe výrazného narušenia horizontálnych vzt’ahov medzi jednotlivými častami táborísk i táboriskami samotnými (napr. Ambrož et al. 1952; Hromada 1998). Geostratigrafia lokalít a analýza spraší v Moravianskom sídliskovom areáli je preto nespochybnitel'ne jednou z najdôležitejších výziev moderného archeologického výskumu, zároveň prostriedkom na stratigrafické upresnenie či porovnanie pozície lokalít v sprašiach vrchného pleniglaciálu (MIS2). S touto víziou bolo pristupované aj k plánovaniu terénneho výskumu.

V roku 2016 sa v Podkovici začal nový terénny výskum a prieskum. Jeho ciel'om bolo nájdenie starších stratigrafických sond a plochy výskumu, realizovaného F. Prošekom v roku 1949, ako aj overenie nálezových okolností a stratigrafickej polohy kultúrnych vrstiev (Hromadová et al. v tlači). Na základe údajov z katastrálnej mapy, historickej ortofotomapy a dokumentácie z výskumu F. Prošeka bola pomocou programu ArcGIS a GPS prístroja vytýčená oporná línia, predstavujúca teoretickú hranicu sondy I/1949. Od tejto línie boli v nadväznosti na terénnu dokumentáciu F. Prošeka vytýčené predpokladané hranice sond I-III a výskumných plôch I-V (obr. 2). Vyhíbené boli prvé dve sondy z plánovaných piatich, s rozmermi $2 \times 1 \mathrm{~m}$. Sonda $1 / 2016$ bola situovaná v mieste predpokladanej sondy III z roku 1949 a sonda 2/2016 v priestore sondy I/1949 (Hromadová et al. v tlači). Hoci boli obe sondy negatívne, priniesli prvú hrubú predstavu o uložení vrstiev v Podkovici (Hromadová et al. v tlači). Počas výskumu v roku 2016 neboli zistené žiadne kultúrne vrstvy ani stopy po starších stratigrafických sondách a plochách výskumu F. Prošeka. S rovnakými ciel'mi sa realizoval výskum v roku 2019, ale tentokrát bola vyhíbená jediná sonda 1/2019 s rozmermi $20 \times 0,5 \mathrm{~m}$. Situovaná bola od rohov sondy $1 \mathrm{z}$ roku $2016 \mathrm{v}$ smere hore a dole svahom (obr. 2). Takto vytýčená sonda mala väčšiu šancu zachytit výkop z roku 2016 a rozsiahle výkopy F. Prošeka. Napokon boli v sonde 1/2019 získané nielen prvé stratigrafické poznatky o vrstvách a starších sondách, ale aj archeologický materiál. Pravdepodobne boli objavené aj pozostatky kultúrnej vrstvy spolu s evidentnou zahĺbenou štruktúrou.

\section{Výsledky výskumu z roku 2019}

\subsection{Stratigrafia a charakteristika archeologickej vrstvy}

Stratigrafická situácia v roku 2019 zodpovedala situácii opísanej F. Prošekom pre sondu I, profily III, IV, ako aj sondu II a pole III, kde sa profily zachovali iba v približnom náčrte (Prošek 1949). Ornica, hrubá 17-30 cm, prekrývala sprašové horizonty. Ostrý prechod medzi ornicou a sprašou svedčí o silnej erózii sprašových sedimentov. Stopy hlbokej orby sa nezistili, len ojedinele v jej juhozápadnej časti. Prejavili sa zvlneným až nepravidelným povrchom spraší zachádzajúcim do ornice. V spodnej a vrchnej časti sondy ostal prechod medzi ornicou ostrý a mierne zvlnený. V centrálnej časti (11.-16. meter) bol prechod pozvol'nejší, nepravidelný a sprevádzali ho početné šedohnedé hlinité záteky. V tejto časti sa tesne pod ornicou objavovala miestami drobná vrstva šedožltého sprašového horizontu, výrazne porušená zátekmi a eróziou. Ornica bola v tejto časti štandardnej hrúbky okolo $25 \mathrm{~cm}$. Humusový horizont postupne prechádzal do niekol'ko centimetrového hrubého horizontu svetložltej spraše s väčším množstvom karbonátových konkrécií (rhizolity a cicváre). V spodnej časti sondy bola táto spraš na 1. metri nekarbonátová.

Súvislejšia antropogénna vrstva ležala od 15./16. metra až po 20. meter (obr. 3), kde sa pôdny profil menil, mizli záteky a pozvol'ný prechod medzi humusovým a podložným, resp. sprašovým horizontom. Ornica bola oddelená od spraše ostro a plynulo. Túto vrstvu sme pri dokumentácii nazvali pracovne „kontakt“, pretože práve v nej sa nachádzali antropogénne pozostatky, presnejšie pozostatky niekdajšej kultúrnej vrstvy v podobe roztrúsených kamenných artefaktov a úlomkov kostí. V tejto časti bol nájdený aj zahĺbený objekt, tzv. „objekt 1“.

Povrch sondy mal na kontakte medzi ornicou a sprašou všetky príznaky opakovane redeponovaných sedimentov. Tento sediment prekrýval alebo zahŕñal archeologické nálezy a pravdepodobne predstavoval erodovanú pôdno-litologickú zložku kultúrnej vrstvy. Jeho štruktúra sa v centrálnej a vrchnej časti sondy líšila, pričom prelomovým bol 16. meter, na ktorom bol nájdený zahíbený objekt (obr. 3).

\subsubsection{Nálezová situácia v sonde}

Celkovo sa v sonde 1/2019 našlo 140 kusov hnutel'ných archeologických nálezov. Prvé kamenné artefakty sa začínali objavovat až na 11. metri v ornici. V tejto časti plochy sa našli ojedinelé nálezy kamennej industrie, zlomok dentália a zásyp sondy 1/2016 (Hromadová et al. v tlači). Ojedinelé nálezy boli nájdené v roku 2019 aj na d'alších metroch a ich počet sa smerom hore svahom zvyšoval. Na 14. metri sa v kontakte s ornicou našiel druhý zlomok dentália.

Na 11.-15. metri bola objavená vertikálna distribúcia nálezov vo vel'mi širokom rozmedzí $(26 \mathrm{~cm})$, vrátane vertikálne položených artefaktov, ktoré sa nachádzali v sekundárnej polohe. Vo vrchnej časti sondy smerom od objektu 1 (16.-20. meter) sa naopak vyskytla híbková distribúcia nálezov v rozmedzí iba niekol'kých centimetrov (približne do $7 \mathrm{~cm}$ ), čo je viac typické pre kultúrne vrstvy. Nálezy v tejto časti sondy boli počas výskumu ponechávané na mieste $\mathrm{v}$ pôvodnej výške pre prípad, že by bolo možné v ich plošnej distribúcii identifikovat’ náznaky pôvodného reliéfu.

\subsubsection{Objekt 1}

Na 16. metri sondy sa nachádzala jemná popolovito-uhlíková vrstva s ojedinelými uhlíkmi s nepravidelným, vel’mi mierne vypuklým povrchom. Tejto vrstve predchádzalo niekol'ko nepravidelne rozložených nálezov kamennej industrie a vel'mi zle zachovaných fragmentov kostí. Dané nálezy neindikovali súvis s konkrétnym pôdnym horizontom, hoci ojedinelé artefakty boli nájdené v spraši. Väčšina týchto nálezov vykazovala nepravidelnú orientáciu, náklon a rôzny prepad v híbkach, čo jednoznačne vylučuje ich polohu in situ.

Pri postupnom zahlbovaní sa ukázalo, že nejde iba o popolovito-uhlíkovú vrstvu, ale o hlbší ohraničený objekt prechádzajúci do stien profilu sondy. Rozmery objektu, resp. priemer pri ústí okrajov bol $70 \mathrm{~cm} \mathrm{~s}$ maximálnou híbkou $15 \mathrm{~cm}$.

Forma objektu po začistení predstavovala oválnu misovitú jamu so široko otvoreným ústím a relatívne plochým dnom. Sonda 1/2019 odkryla pravdepodobne len jej stredovú čast', ked'že zvyšky výplne pokračovali smerom do oboch profilov, predovšetkým do juhozápadného profilu, kam sa zvažovala jej väčšia časté. Ústie jamy nebolo kompletne odkryté pre poškodenie nadložnej vrstvy, resp. o charaktere jej povrchu vo vrstve nemáme informácie. 
Popolovitá vrstva sa hned' na povrchu javila ako vel'mi mierne vypuklá a farebne odlišná šošovka, ktorú prakticky prekrývala ornica.

Hranice výplne objektu, teda prechod do sprašovej vrstvy bol pomerne jasný, hoci nebol ostro ohraničený a steny s dnom postupne splývali s okolitý sedimentom. Dno malo charakteristickú štruktúru zmiešaného sedimentu ako nepravidelné sfarbenie a koncentrácie sedimentov rôznej zrnitosti vytvárajúce škvrnitý efekt (zmes svetložltej spraše a popolovitej výplne rôzneho sfarbenia) a odlišujúcich sa od okolitých sprašových sedimentov. Postupne sa objavili drobné karbonátové konkrécie, typické pre podložnú spraš. V profile sondy 1/2019 vykazujú hranice objektu príznaky erózie smerom na západ, a to predovšetkým vo vrchných častiach. Jama bola v tejto časti plytšia, s menej strmým okrajom a vel'mi mierne erodovala smerom dolu svahom.

V rámci vertikálnej distribúcie nálezov sa neprejavovali markantné rozdiely. Naopak, viditel'né boli odlišnosti v plošnej distribúcii nálezov, ktoré sa koncentrovali predovšetkým smerom k juhozápadnému profilu. Začistenie profilov sondy 1/2019 a mikroprofilu (obr. 4) objektu ukázalo na niektoré detaily zaplnenia jamy. Okraje sa v mikroprofile zvažovali smerom na juh, teda dole svahom. Hranice objektu tu prakticky absentovali, resp. boli naširoko otvorené vo vzţahu k povrchu a dnu objektu. Týmto smerom objekt erodoval a bol v tomto mieste plytší, zatial’ čo opačná hranica mala prudšie steny. V južnej časti bola hranica objektu tiež nejasná, výplň pozvol'ne prechádzala do okolitej vrstvy. Zo severnej a východnej strany bolo ohraničenie jasnejšie. Dno a steny zahĺbenia boli prekryté sedimentom takmer bez nálezov, s výnimkou prepálených kostí, určených na datovanie. Medzi okrajom objektu sa na viacerých miestach výplňové sedimenty zvrstvovali a vytvárali mikrovrstvy rôzne sfarbenej spraše a tmavšej výplne (obr. 4: A, C). Tieto mikrovrstvy mali rôzny náklon, podl'a charakteru okraju objektu. Z juhu zasahovali takmer do polovice objektu a neobsahovali žiadne nálezy ani viditel'né organicko-minerálne prvky. Mohlo by íst o záteky do objektu počas erózie stien, ako aj stopy jeho čistenia. V prospech druhej možnosti hovorí distribúcia nálezov a štruktúra popolovitej zložky, ktorá bola uložená na týchto vrstvách pod rovnakým uhlom, vytvárajúc akési druhé dno. Značná čast artefaktov sa koncentrovala $v$ strednej a juhozápadnej časti
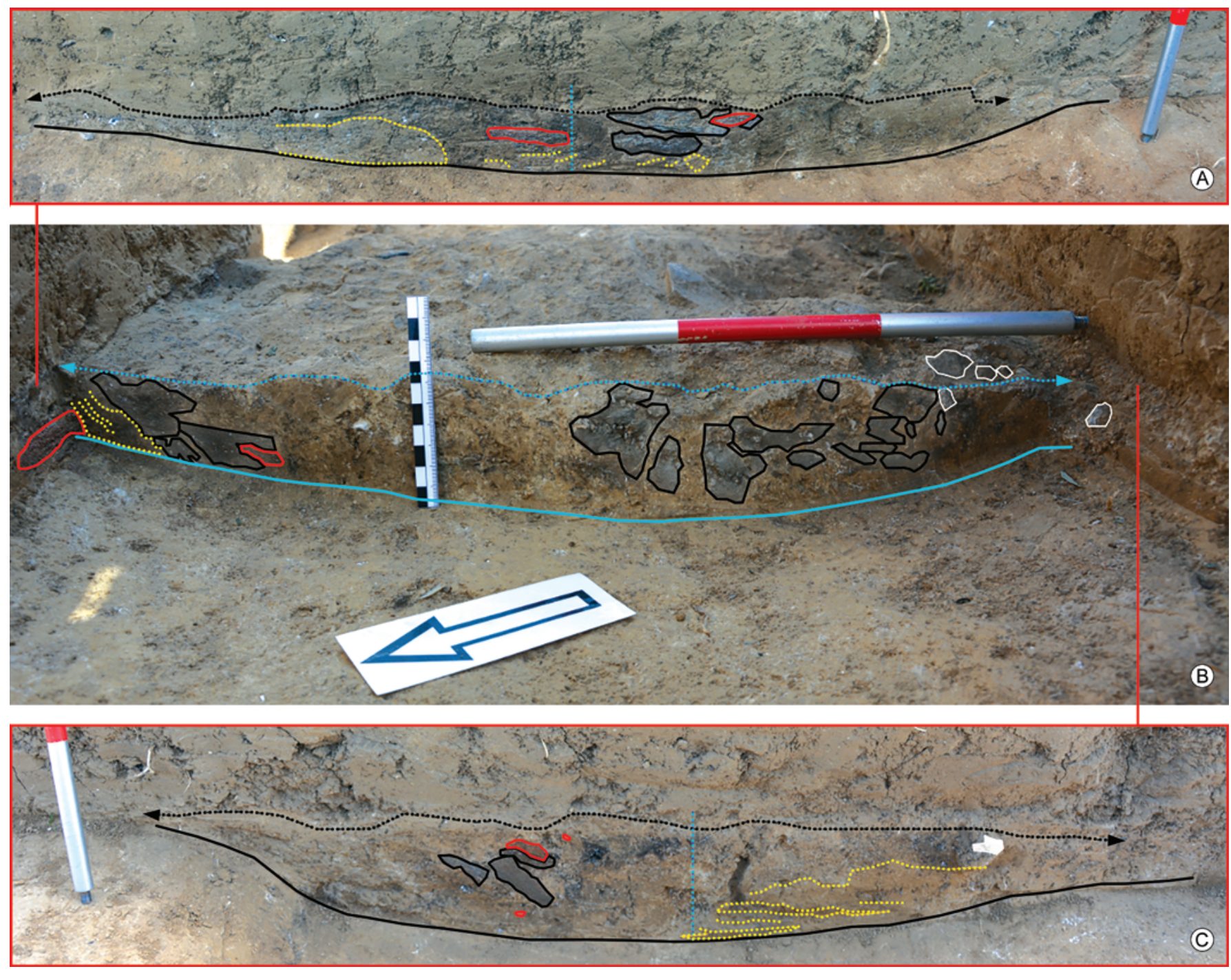

Obr. 4. Profily objektu 1 v sonde 1/2019. A - objekt v SV profile; B - priečny prierez výplňou objektu; C - objekt v JZ profile. Legenda k obrázku je v obr. 5. Vyhotovila B. Hromadová, foto A. Nemergut.

Fig. 4. Profiles of feature 1 in trench 1/2019. A-feature in the NE profile; B-cross-section with the filling of feature 1; C-feature in the SW profile. For details see caption in Fig. 5. Graphics by B. Hromadová, photo by A. Nemergut. 
jamy a organicko-minerálny substrát zahŕňajúci tieto nálezy bol výrazne sfarbený, pomerne rôznorodý (obr. 5: A, B). Možno ho rozdelit na dva typy. Prvým je popolovitý sediment s ojedinelými uhlíkmi, zlomkami okru a prepálenými artefaktami - tvorí väčšiu časť výplne objektu. Druhým je silne prepálená popolovito-uhlíková vrstva, obsahujúca drobné uhlíky a prepálené kosti, prepálené kamenné artefakty, zlomky okru (žltého a červeného) a mohutné kusy drobivej sl'udy, prípadne kremenca. Tento typ výplne sa nachádzal aj v jame, v koncentráciách, a to predovšetkým v juhozápadnej časti, kde zapíňal jamu prakticky na celú jej híbku. Výrazná koncentrácia sl’udy sa tiež nachádzala v severovýchodnej časti a pokračovala do profilu. Vzhl'adom na tafonomický stav kostí a kamennej industrie obsah objektu korešpondoval s okolitou antropogénnou vrstvou, plynulo do nej prechádzal a je teda jej súčastou.

\subsection{Archeologické nálezy}

\subsubsection{Nálezy štiepanej kamennej industrie}

V roku 2019 bolo nájdených celkovo 84 ks štiepanej kamennej industrie. Jednotlivé nálezy nevykazujú výraznejšie staršie poškodenia na povrchu ani ohladenia hrán, ktoré by svedčili o výrazných procesoch pri ich premiestnení. Nástroje boli kalcifikované, silicity silne bielo-patinované. Časť artefaktov bola poškodená v modernej dobe (recentné mechanické poškodenia patinovaného povrchu) alebo prepálená (obr. 6: 11, 14, 15). Materiálovo sa vyskytuje bielokarpatský rádiolarit spolu so silicitmi bližšie nešpecifikovaného pôvodu (obr. 6). V kamennej industrii dominujú malé úštepy, od 16. metra sa však začali objavovat' vel'ké artefakty, medzi nimi aj ojedinelé nástroje a čepele (tab. 1). Z nástrojov možno spomenút dve retušované čepele, zlomené rydlo a typický hrot s vrubom (obr. 6: 1), z d'alších artefaktov neretušované čepele, čepiel'ky a rydlové triesky. Hrot s vrubom bol nájdený na 17. metri, blízko jamy. Štiepaná industria z objektu a z antropogénnej vrstvy je totožná, s výnimkou prítomnosti prepálených kamenných artefaktov v objekte. Nevykazuje žiadne rozdiely, či už z typologického hl'adiska, surovinového zloženia, vel'kosti, alebo fragmentácie artefaktov (Hromadová et al. v tlači). Typologické a technologické vzt̉ahy s kolekciou F. Prošeka (Ambrož et al. 1952) sú v súčasnosti predmetom výskumu a budú publikované v komplexnejšej štúdii (Klaric, Hromadová v príp.).
Zaujímavostou zo stratigrafického hl’adiska je nález úštepu so stopami mrazového poškodenia (cryogenic cupules; obr. 6: 16). Takéto mrazové poškodenie svedčí o kryogénnych procesoch, prebiehajúcich pri formovaní vrstvy. V budúcnosti bude nutné sledovat vztah sprašových vrstiev, v ktorých ležia artefakty v Podkovici vo vztahu ku kryogénnym procesom. Mrazové trhliny a iné kryogénne poškodenia boli identifikované aj na susednej lokalite Lopata II a predstavujú potenciálne vel'mi zaujímavý datovací aj komparatívny prvok.

\subsubsection{Faunistický materiál}

Je silne zvetraný, dekalcifikovaný, fragmentovaný s postupujúcou koróziou povrchu a mikročasticami oxidu manganičitého (Fernández-Jalvo, Andrews 2016), pri vyberaní z vrstvy sa rýchlo rozpadal. Čast’ nálezov z jamy je taktiež silno prepálená. Stav kosteného materiálu zodpovedá vel'mi malej híbke jeho uloženia, v dosahu orby, koreňov i meteorologických činitel’ov. Kompletne sa zachovali iba najmenšie kostrové elementy ako tretí prstový článok, zub, či sezamská kost̉ soba, pričom všetky boli rozlámané na viac častí. Spracovaný súbor pozostával celkovo z 33 vzoriek, z ktorých sa šesť nepodarilo bližšie identifikovat a 19 kusov iba do vel'kostných kategórií (1 vel'ký cicavec/ Mammuthus primigenius, 7 vel'kých cicavcov/kôň príp. pratur/ zubor, 10 stredne vel'kých cicavcov/sob príp. vlk, 1 malý cicavec/ líška alebo zajac; Hue 1907; Lyman 2008; Prat 1987; Schmid 1972 a pod.). Do taxónu sa podarilo priradit len osem kusov. Jeden fragment lamely zuba patril mamutovi (Mammuthus primigenius), zub, tretí prstový článok, fragment metapódia, sezamská kost' sobovi (Rangifer tarandus) a incisivus, fragment vretennej kosti a pätová kost’ prislúchali zajacovi (Lepus sp.). Išlo nepochybne o zajaca fosílneho, nakol'ko vzorky z neho boli zachované úplne rovnako ako zvyšok materiálu a navyše boli pokryté vyzrážaným uhličitanom vápenatým. Všetok určitel'ný materiál, t. j. pozostatky soba (Rangifer tarandus) a zajaca (Lepus sp.) sa vyskytol výhradne v jame, resp. v kontexte zahĺbeného objektu. Lamely mamutej stoličky a zub soba pochádzali taktiež z kontextu jamy, avšak z časti kontaktu alebo ornice.

Celkovo bol spracovaný súbor homogénny, bez akýchkol’vek moderných prímesí. Na jednom fragmente kompakty diafýzy dlhej kosti stredne vel'kého cicavca sa podarilo identifikovat stopu po záreze kamenným nástrojom ako doklad o činnosti lovcov. S najväčšou pravdepodobnost’ou ide o tzv. filleting mark,

\begin{tabular}{|c|c|c|c|c|c|}
\hline Typ artefaktu/materiál & Silicit & Rádiolarit & Prepálený artefakt & Bližšie neurčený & Celkový počet \\
\hline Hrebeňová čepel' & - & - & 1 & - & 1 \\
\hline Čepel' & 2 & 1 & - & - & 3 \\
\hline Hrebeňová čepiel'ka & - & 1 & & - & 1 \\
\hline Čepiel'ka & - & 1 & - & - & 1 \\
\hline Fragment čepiel'ky & 8 & 3 & 1 & - & 12 \\
\hline Rydlová trieska & 3 & - & - & - & 3 \\
\hline Úštep & 10 & 9 & 2 & 1 & 22 \\
\hline Fragmenty úštepov a malé úštepy & 13 & 4 & 4 & 4 & 25 \\
\hline Hrot s vrubom & 1 & - & - & - & 1 \\
\hline Fragment rydla & - & - & 1 & - & 1 \\
\hline Retušovaná čepel’ & 1 & 1 & - & - & 2 \\
\hline Spolu & 44 & 24 & 11 & 5 & 84 \\
\hline
\end{tabular}

Tab. 1. Klasifikácia štiepanej kamennej industrie podl’a surovinového zloženia.

Tab. 1. Lithic industry and raw material classification. 


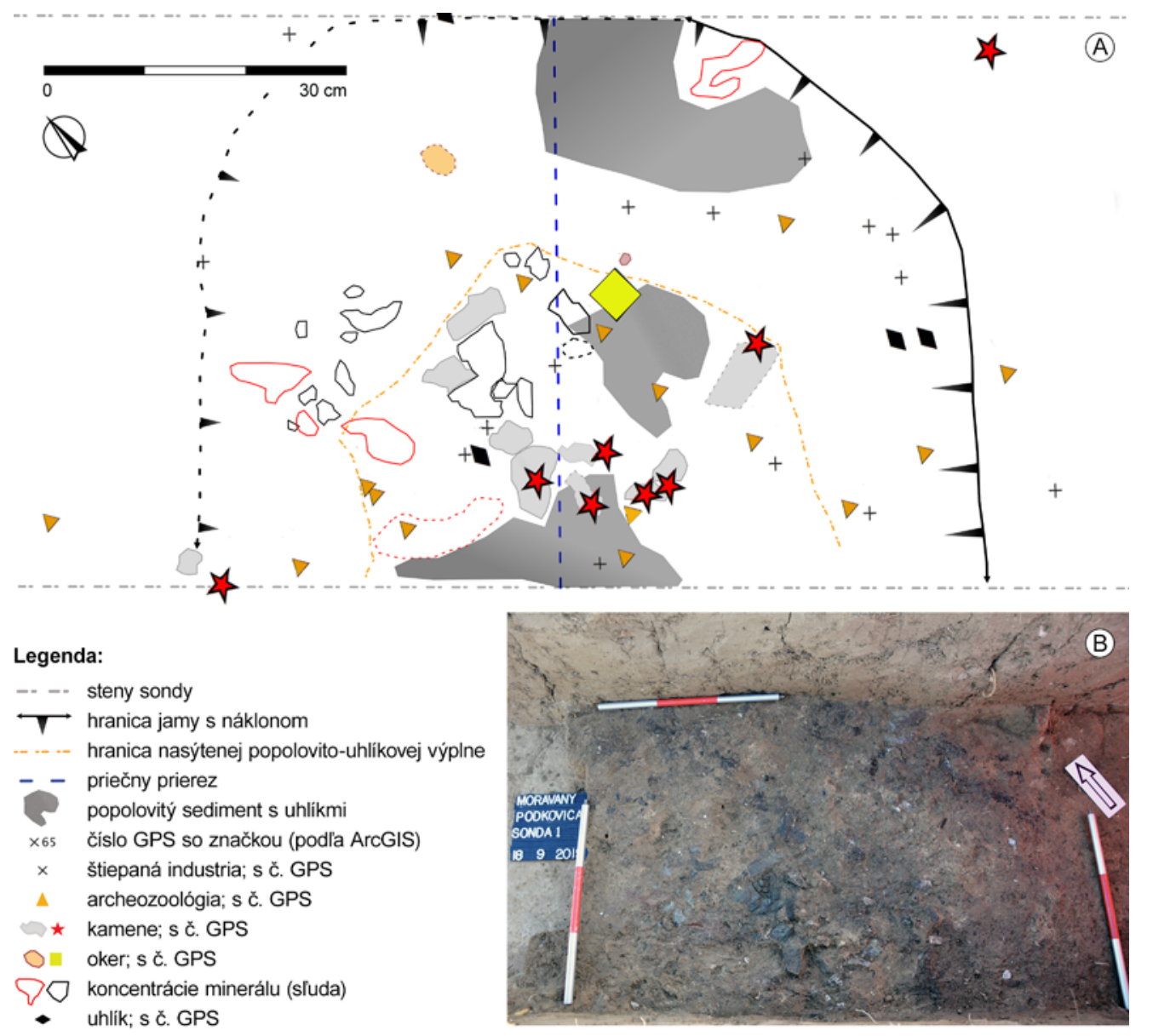

Obr. 5. Pôdorys objektu 1 v sonde 1/2019. A - celková distribúcia archeologických nálezov v objekte; B - pohl'ad na objekt po druhom začistení povrchu. Vyhotovila B. Hromadová, foto A. Nemergut. Fig. 5. Plan of feature 1 in trench 1/2019. A - spatial distribution of the archaeological finds in feature; $B$ - view of feature 1 after the second surface cleaning. Graphics by B. Hromadová, photo by A. Nemergut.

teda stopa po odrezávaní mäsa z kosti (Binford 1981; Wojtal 2007). O jej autentickom pôvode svedčí čiastočné prekrytie zárezu povlakom uhličitanu vápenatého. Až 11 z 33 vzoriek nieslo známky prepálenia v ohni. Nakol'ko mali elementy prevažne čiernu, sivú až bielu farbu, prešli pomerne vysokými teplotami horenia, od 500 do $800{ }^{\circ} \mathrm{C}$ (graf 1; Dokládal 1999, 113, 186). To indikuje ciel'avedomé umiestňovanie kostí do ohňa a určite nesúvisia s prírodným požiarom.

Celkovo nájdené spektrum fauny plne zodpovedá taxónom bežne nachádzaným na iných gravettienskych lokalitách na Považí či na území Moravy. Už tradične je z určitel'ných kostí prevládajúcim taxónom na Podkovici sob, ktorý bol zjavne tažiskovým loveným druhom aj na okolitých lokalitách z rovnakého obdobia (napr. Lipecki, Wojtal 1998; Vlačiky 2012).
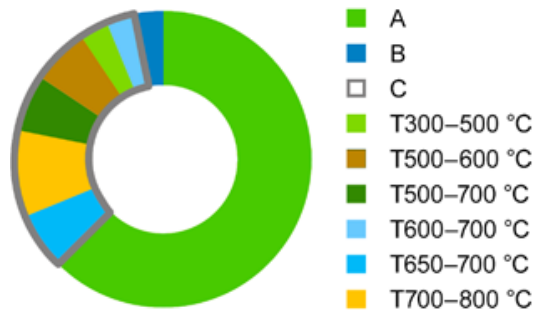

Graf 1. Intencionálna modifikácia kostí v sonde 1/2019. A - nemodifikované kosti; B - kosti so zárezom; C - prepálené kosti. Vyhotovila B. Hromadová, M. Vlačiky.

Graph 1. Intentional bone modifications from trench 1/2019. A - non-modified bones; $B$ - bone with incisions; $C$ - burned bones. Graphics by B. Hromadová, M. Vlačiky.

\subsubsection{Vyhodnotenie nálezov z objektu 1}

Objekt bol pomerne bohatý na nálezy. Nachádzali sa v ňom prepálené kosti, štiepaná kamenná industria, oker a neopracované kamene, zastúpené horninami a minerálmi. V zahíbenej časti objektu sa koncentrovali predovšetkým kamene a prepálené kosti. Kamenná industria sa nachádzala skôr na okraji tejto koncentrácie, s výnimkou niekol'kých prepálených kusov.

Kamene, resp. horniny boli zastúpené prepáleným kremencom (makroskopicky posúdil Mgr. Michal Cheben, PhD.) a niektoré kusy je možné poskladat dohromady. Nejde však o sekundárne zlomené fragmenty, ked’že miesta zlomov sú zasintrované. V̌̌etky ležali na jednom mieste, premiešané s kusmi prepálených kostí. Iné kusy prepálených kostí a kamennej industrie sa nachádzali aj mimo týchto zhlukov, roztrúsené nepravidelne v povrchovej časti objektu (obr. 5).

Vzhl'adom na výsledky faunistickej analýzy a celkového kontextu (absencia spálených kostí mimo kontextu jamy, prítomnost̉ d'alších prepálených predmetov a pod.) je možné s istotou potvrdit ich ciel'avedomé spálenie v jame alebo mimo nej.

Spolu s kremencom sa v jame nachádzali pomerne vel'ké kusy drobivého červeno a šedo sfarbeného lesklého minerálu. Z najhrubších kusov minerálu premiešaného spolu s výplňou jamy boli odobraté vzorky na mineralogickú a chemickú analýzu. Mikroskopické a mikrochemické analýzy boli vykonané v Laboratóriu elektrónovej mikroanalýzy Štátneho geologického ústavu Dionýza Štúra v Bratislave. Stereo mikroskopom NIKON SMZ18 boli v makrovzorkách identifikované uhlíky, úlomky kostí, artefaktov, tiež zhluky slúd (muskovit a biotit), kremenné zrná a povlaky Fe-oxihydroxidov na minerálnych zrnách (obr. 7: 1-6). Na detailnejšiu mikroskopickú a mikrochemickú identifikáciu bol použitý 


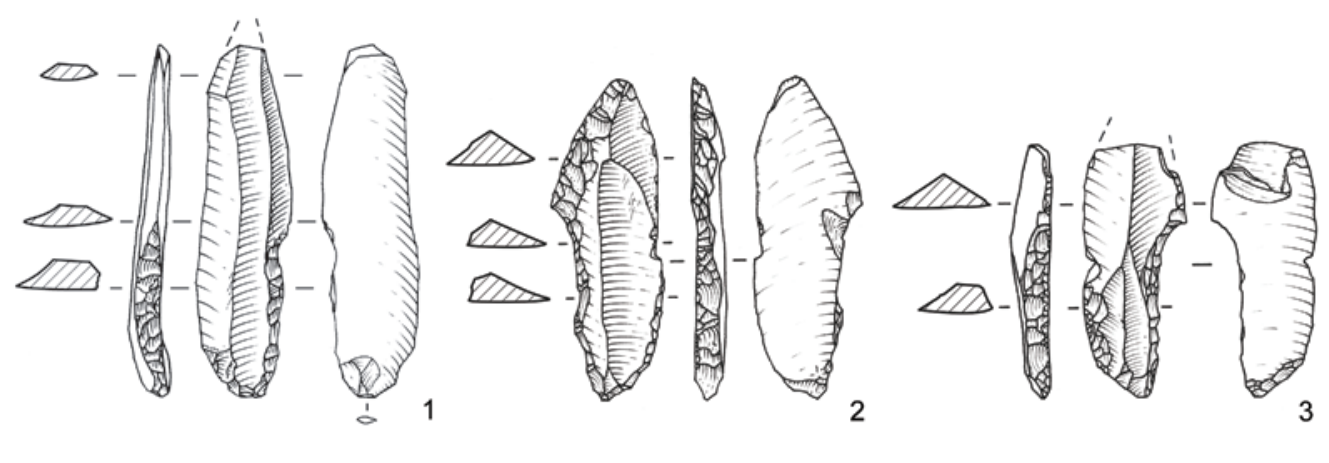

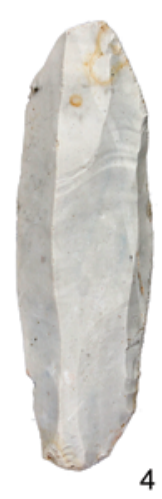

4
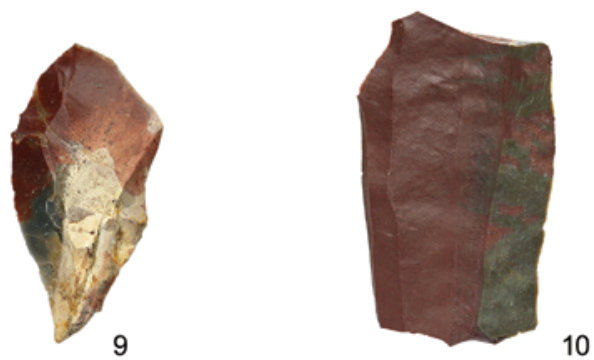

10

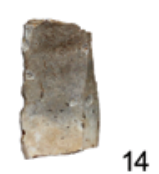

14
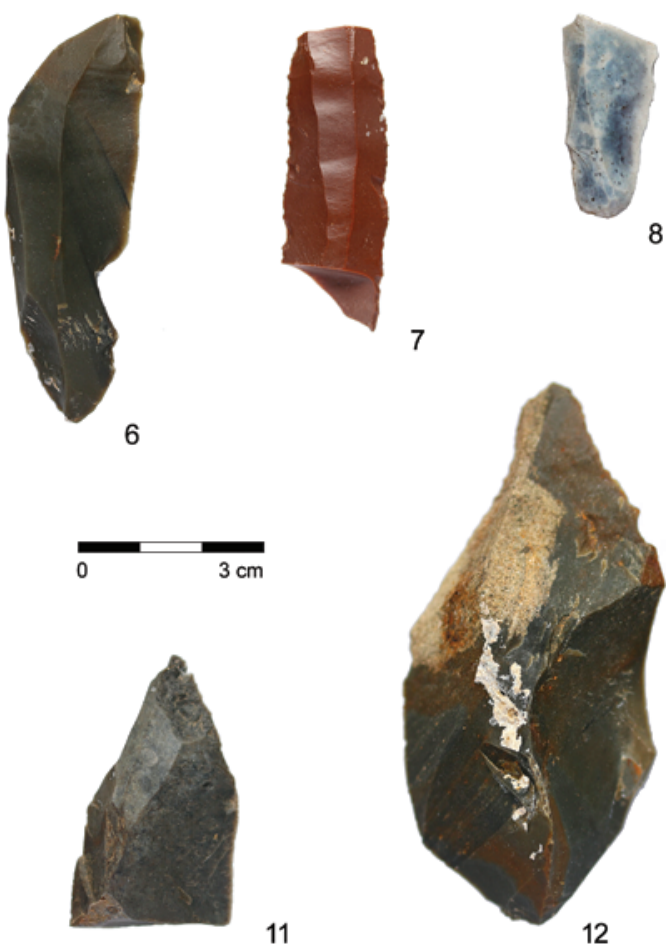

11

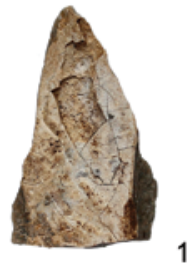

15

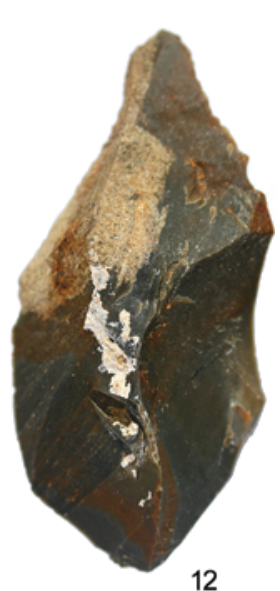

Obr. 6. Výber kamennej industrie a surovín. 1-3- hroty s vrubom z lokality Podkovica (1 - objekt 1/2019; 2 - zbierka L. Zotza; 3 - zbierka F. Prošeka); 4, 5, 8 - silicit; 6, 7, 9, 10, 12, 13 - rádiolarit; 11, 14, 15 - prepálené artefakty; 16 - artefakt poškodený mrazom. Vyhotovil L. Klaric.

Fig. 6. Selection of the lithic industry and raw material. 1-3 - shouldered points from Podkovica ( 1 - feature 1/2019; 2 - collection of L. Zotz; 3 - collection of F. Prošek); 4, 5, 8-flint; 6, 7, 9, 10, 12, 13 -radiolarite; 11, 14, 15 - burned artefacts; 16 - artefact with cryogenic cupules. Graphics, drawing and photo by L. Klaric. mikroanalyzátor CAMECA SX100, vyhotovené BSE snímky s obrazom odrazených elektrónov a EDS spektier na analýzu chemického zloženia (obr. 7: 7-12). Z mineralogického hl'adiska boli identifikované zrná: muskovit, alterovaný muskovit, biotit (obr. 7: 12), chloritizovaný biotit (obr. 7: 7), rutil (obr. 7: 7), kalcit, aragonit (obr. 7: 11), karbonát (obr. 7: 8), chlorit, kremeň (obr. 7: 8), smektit (obr. 7: 9), illit (?) a goethit (laboratórne určil RNDr. Patrik Konečný, PhD., Laboratórium elektrón-optických metód, Štátny geologický ústav Dionýza Štúra, d’alej ŠGDÚŠ).

Z mineralogického vyhodnotenia je zrejmé, že drobivý lesklý materiál obsahuje predovšetkým sl'udu. Tá je v okolí Moravian súčastou hornín, tvoriacich podložie miestnych spraší, kryštalinikum. Zdrojom sl'udy v zahĺbenom objekte by teda mohli byt biotitické a muskoviticko biotitické granity a granodiority, ako aj biotitické pararuly pochádzajúce z blízkeho okolia lokalít, prinesené na lokalitu a uložené do zahíbenej štruktúry. Časom pravdepodobne zvetrali a vytvorili akumuláciu rôznych farebne odlíšitel'ných sl'úd. Ďalšie údaje o ich pôvode môže priniesț geologická prospekcia a rozsiahlejšie geochemické, mineralogické či mikromorfologické porovnanie materiálu z archeologického výskumu a zo zdrojov. Vytvorenie takejto akumulácie v zahĺbenom objekte, spolu s kúskami kremencov, prepálených artefaktov a okru, nie je v danom štádiu výskumu zatial' vysvetlitel'né ani nenachádza analógie na okolitých, či vzdialenejších gravettienskych lokalitách a bude predmetom d’alšieho výskumu.

V blízkom okolí objektu sa koncentrovali fragmenty kostí, z nástrojov je zaujímavý nález hrotu s vrubom a sobieho moláru. Ich poloha in situ je síce stále nepotvrdená, rovnako ako charakter prechodu medzi objektom a okolitou vrstvou, ich zloženie a spomenuté charakteristiky však korešpondujú s obsahom výplne objektu. 

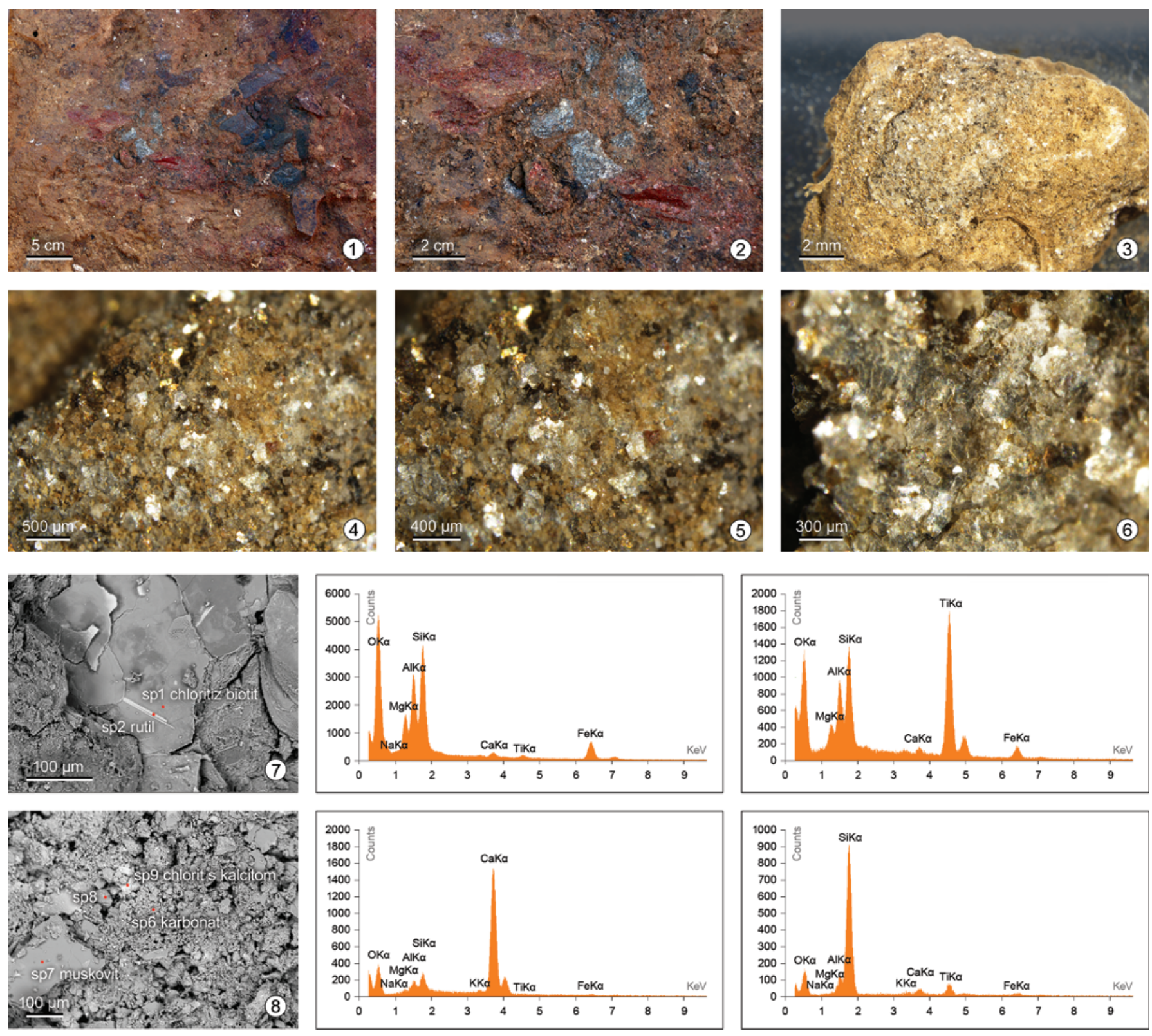

\subsection{Datovanie a chronokultúrne zaradenie archeologických nálezov}

Chronokultúrne zaradenie ostáva azda najvýznamnejším problémom pri interpretovaní lokality Moravany nad Váhom-Podkovica. Datovanie nálezov pomocou radiouhlíkovej metódy komplikuje zlá zachovaloste organického materiálu na lokalite s príliš nízkym množstvom analyzovatel'ného kolagénu. Jediné dátumy z lokality Podkovica, 22680 a 22200 uncal BP (graf 2; Hromada 1997; Verpoorte 2002, Tab. 6), pochádzajú z kúskov mamutoviny z povrchového zberu. Získané údaje poukazujú na relatívne „mladý“ pôvod gravettienskeho materiálu a boli by dobrým kompromisom $\mathrm{k}$ ostatným dátam, získaným $\mathrm{z}$ moravianskeho regiónu a moravských post-pavlovienskych nálezísk (Verpoorte 2002, 315). Napriek tomu tieto datovania poukazujú na viacero problémov. Celkovo problematický je zberový pôvod materiálu a absencia kontextu, viackrát kritizované v literatúre (Verpoorte 2002, 315). Samotná surovina, mamutovina, je v súčasnosti tiež považovaná za diskutabilný materiál nevhodný na získanie absolútnych dát bez podrobných znalostí o kontexte nálezu. Okrem toho samotná datovacia krivka po kalibrovaní spomenutých starších údajov dáva vel'mi široký interval (95,4\%,
2 sigmas; graf 2) a pri časovom rozpätí 1000 a 1600 rokov ju možno považovat’ za nepresnú.

V roku 2019 bola zo zahĺbeného objektu získaná malá séria vzoriek prepálených kostí, z ktorých prvé dve vzorky boli v roku 2020 odoslané na datovanie do laboratória v pol'skej Poznani. Fakt, že vzorky neboli vybraté z porušenej antropogénnej vrstvy, ale z evidentnej štruktúry uzavretého rázu, zvyšoval šancu na získanie vhodnejších a presnejších dát, spojitel'ných s konkrétnym obsahom jamy (určitel'né sobie kosti, patinované silicity atd'.).

Prvá vzorka (č. 62, Poz-129762), s výsledkom $20299 \pm 420$ uncal BP (graf 2), pochádza z okrajovej SV časti jamy. Druhá vzorka (č. 69, Poz-129763) bola získaná z povrchu centrálnej časti výplne objektu a jej dátum je $17160 \pm 690$ uncal BP (graf 2).

Výrazným rozdielom v porovnaní s predošlými vzorkami je „omladenie“ lokality do intervalu medzi 20-18 Ky BP (uncal). Takéto zaradenie lokality poskytuje reálnejšie údaje z hl’adiska pôvodu datovaného materiálu aj stratigrafického zaradenia sprašových vrstiev. Chronologicky korešponduje aj s epigravettienom, resp. s fázou LGM a post-LGM. Na druhej strane, obe datovania 

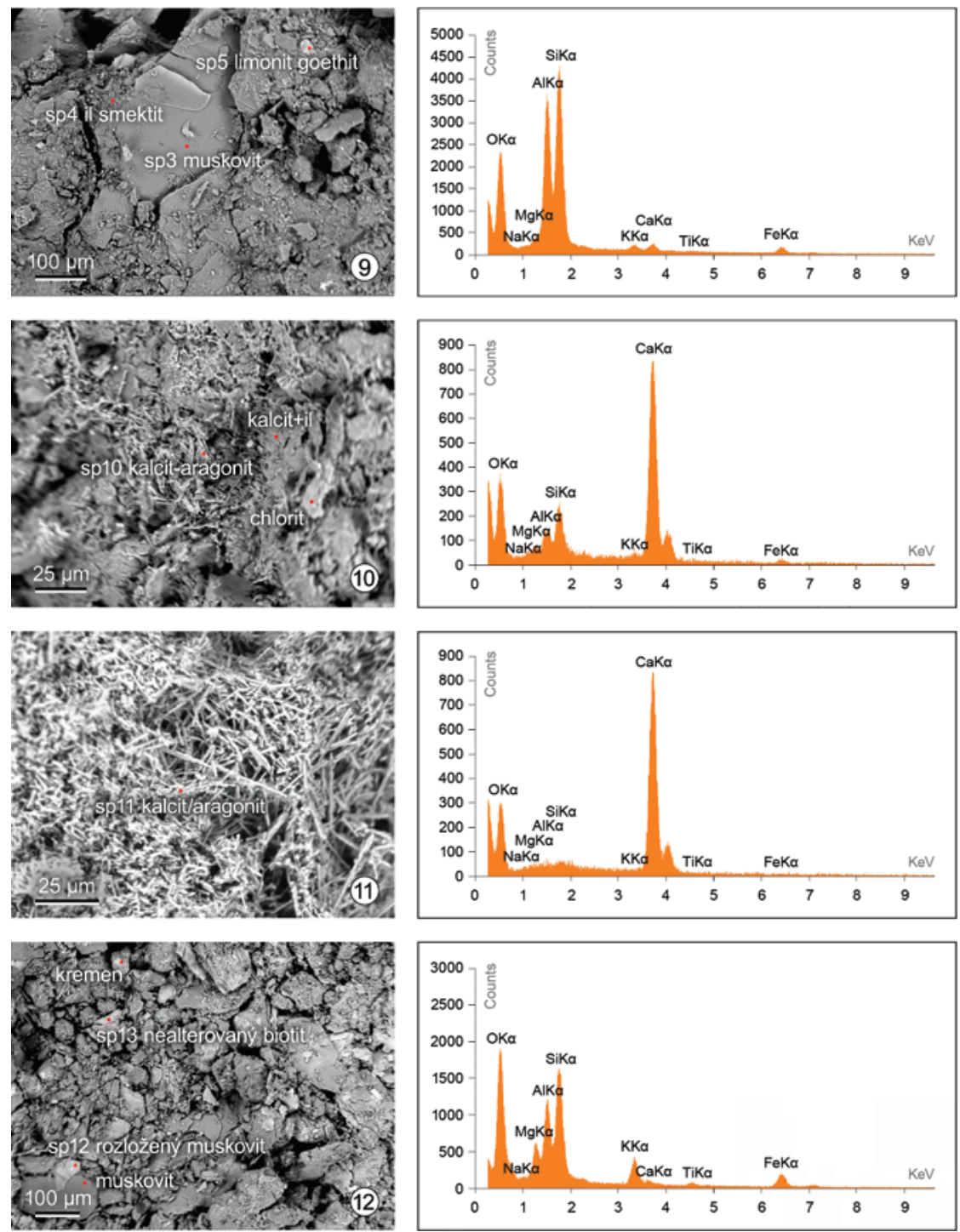

Obr. 7. Mikroskopická a mikrochemická analýza spraší vobjekte 1. Použitý stereo mikroskop NIKON SMZ18 a mikroanalyzátor CAMECA SX100 (BSE snímky a EDS spektrá). Vyhotovili M. Moravcová Ábelová, P. Konečný. Popis v texte.

Fig. 7. Microscopic and microchemical analysis of the loess deposit in feature 1. Digital image taken with a NIKON SMZ18 stereo microscope and CAMECA SX100 microanalyzer (BSE image and EDS spectra). Graphics by M. Moravcová Ábelová, P. Konečný. Description in the text. vykazujú diskrepanciu niekol'ko tisíc rokov ( \pm 420 až \pm 450 rokov) a výraznú štandardnú deviáciu, čo vážne ovplyvňuje ich presnost’ po kalibrácii. Pri dvoch $\Sigma$ totiž datovania poskytujú kalibračné intervaly 2200 až 3300 rokov (graf 2). V súčasnosti možno zohl'adnit celý rad príčin, ktoré by mohli viest' k širokému intervalu, napr. viaceré fázy osídlenia lokality a výplne objektu či kontaminácia mladším sedimentom. Príčina takéhoto širokého intervalu by mohla tkviet taktiež v čistení a v protokole prípravy vzoriek v laboratóriu. Dôvody bude možné presnejšie vyhodnotit? až po získaní širšieho spektra dát či dokopaní objektu, pričom bude nutné odoslat' na datovania aj d'alšie odobraté vzorky z rovnakého kontextu.

Bližšie kultúrne zaradenie lokality na základe chronologicky citlivých artefaktov (hroty s vrubom) stažuje fakt, že lokalita v Podkovici poskytuje ich etalónovú zbierku, pochádzajúcu predovšetkým zo zberov a starých výskumov. Materiál mimo kontextu datovaných kultúrnych vrstiev tak stráca svoj chronologický potenciál. Z uvedených dôvodov je materiál možné zatial' chronokultúrne zaradit len rámcovo do neskorého obdobia gravettienu s dôrazom na to, že je nutný d'alší archeologický a geostratigrafický výskum.

\subsection{Poloha sond z výskumu F. Prošeka}

Poloha sondy z výskumu F. Prošeka z roku 1949, ktorých identifikácia bola jedným zo základných cielov revízneho výskumu ostala do posledného dňa diskutabilná. V sprašových vrstvách sú bežne staré sondy dobre viditel'né a je ich možné nájst’ už pod ornicou, podl’a čoho boli plánované aj výkopy sond v rokoch 2016 a 2019. Smerodajnou bola zachovaná dokumentácia F. Prošeka, ako aj orientácia početných mnohoročných zberov kamenných artefaktov. Vytipovaná poloha nových sond bola vo vrchnej časti zberovej zóny. Výskum sondy 1/2016 priniesol predpoklad, že stratigraficky nami vybraná čast̉ sprašového chrbta zodpovedá situácii opísanej tímom F. Prošeka pre sondu I/1949, presnejšie priestoru medzi stratigrafickými sondami II-IV (Hromadová et al. v tlači).

Výskum F. Prošeka sa kvalitatívne líšil a rôzne časti plochy boli kopané rôznym spôsobom. Sonda I/1949 mala skôr stratigrafický charakter a jej ciel'om bol prierez sprašovým chrbtom s dížkou 47 metrov mapujúcim jeho geomorfologickú stavbu. Celkovú priemernú híbku mala do $50 \mathrm{~cm}$, jednotlivé stratigrafické sondy v nej (taktiež označované rímskymi číslicami) aj niekol'ko metrov (obr. 2; Prošek 1949). Na sondu I/1949 nadväzovali d’alšie dlhé 


\begin{tabular}{|l|l|l|l|l|}
\hline Lab č. & Materiál & $\begin{array}{l}\text { Dátum } \\
\text { (uncal BP) }\end{array}$ & $\begin{array}{l}\text { Dát. interval } \\
\text { (cal BP)-95,4\% }\end{array}$ & $\begin{array}{l}\text { Spôsob } \\
\text { získania }\end{array}$ \\
\hline GrN-26749 & kost', mamut & $22680 \pm 400$ & $27711-26094$ & zber, 1953 \\
\hline GrN-26750 & kost', mamut & $22200 \pm 220$ & $27036-25973$ & zber, 1976 \\
\hline Poz-129762 & kostený uhlik & $20299 \pm 420$ & $25620-23406$ & objekt 1/2019 \\
\hline Poz-129763 & kostený uhlík & $17160 \pm 690$ & $22496-19160$ & objekt $1 / 2019$ \\
\hline
\end{tabular}

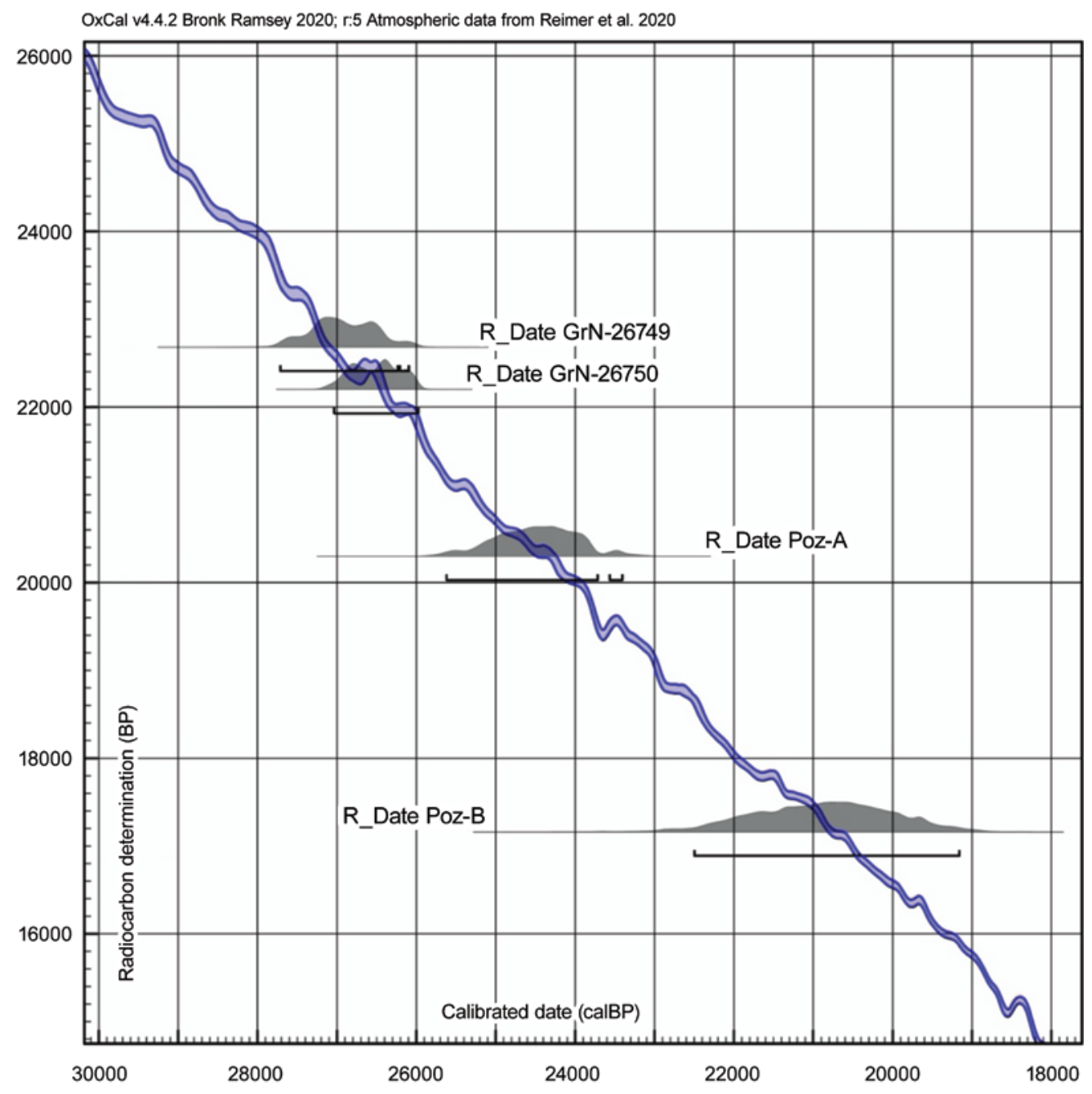

Graf 2. Datovania z Moravian nad Váhom-Podkovice (upravené podl'a Verpoorte 2002), kalibrované podl'a OxCal 4.4. (Bronk Ramsey 2021) a InCal 20 (Reimer et al. 2020). Vyhotovil L. Klaric.

Graph 2. Radiocarbon dates from Moravany nad Váhom-Podkovica (modified according to the Verpoorte 2002), calibrated in OxCal 4.4. (Bronk Ramsey 2021) and InCal 20 (Reimer et al. 2020). Graphics by L. Klaric.

stratigrafické sondy pretínajúce sprašový chrbát (II a III; obr. 2). Tie boli v prípade nájdenia kamenných artefaktov (či už vo vrstve alebo v rámci zberov) rozširované na menšie plochy, tzv. pole (I-V; obr. 2). Pole I a II však boli kopané do výrazne menšej híbky, nepresahujúcej svetložltú spraš s karbonátovými konkréciami. Ich ciel'om bolo mapovanie archeologických nálezov, objektov a ich planigrafie. Planigrafické plány sa, bohužial', nezachovali. Nálezy kamennej industrie a objektov F. Prošek hlásil z oblasti pol’a I, II a V, rovnako aj zo záverov sond II a III. Naopak, na poli III sa pravdepodobne našla staršia sonda L. Zotza a V. Vlka z konca 30. rokov (obr. 2). Podl'a F. Prošeka sa najhoršie archeologické vrstvy zachovali v najvyšších častiach chrbta, pričom smerom ku krajom sa zvažovali miestami až do híbky $1 \mathrm{~m}$. Výskum F. Prošeka bol v roku 1949 orientovaný smerom do vrchných častí chrbta. Výkop bol však zastavený na hranici pol’a č. 1098 a d'alej nepokračoval pravdepodobne preto, že na susednom poli, patriacemu inému majitelovi, bola vysadená kukurica (obr. 2).
Pôvodne sa predpokladalo, že sonda 2016 alebo 2019 zasiahne výkop F. Prošeka v priestore metrov 23.-24. sondy I/1949 (obr. 2). Sondy z rokov 2016 a 2019 boli kopané do híbky približne $50 \mathrm{~cm}$, v plánovaní bola zohl’adnená možná poloha a híbka Proškových sond. Prekvapivým faktom sa stalo, že zásyp vyššie položenej sondy $1 / 2016$ bol v profile aj pri začistovaní extrémne slabo viditel'ný (na 8.-10. metra) a iba nepatrne odlíšitel'ný od okolitých vrstiev. Príčinou mohla byṫ nevel'ká híbka sondy aj dôsledné oddelenie jednotlivých vrstiev pri zasypávaní. Vznikla tak obava, či budú staré sondy v profiloch vôbec viditel'né.

Najperspektívnejšou pri hl'adaní pozostatkov povojnových sond sa ukázala spodná časte dlhej sondy 1/2019. V celkovom zábere sa jej spodná čast̉ (2.-5. meter) javila výrazne odlišná od centrálnej a vrchnej časti, v profile bol identifikovaný odlišný a poškodený horizont. Ornica $\mathrm{v}$ tejto časti dosahovala štandardnú hrúbku okolo $30 \mathrm{~cm}$. Pod ním sa nachádzal aspoň 7 cm hlboký bližšie neurčený zmiešaný horizont bez nálezov. 
Na 3. metri sa v híbke viac ako $30 \mathrm{~cm}$ pod povrchom objavil kus starej tehloviny. Prechod medzi podložím a nadložím sa javil ako nepravidelný až polámaný a bolo tažké určit konkrétnu hranicu medzi sprašou a ornicou. Až na dne sondy sa po začistení objavila svetložltá spraš bez karbonátových konkrécií.

Takýto profil sa nevyskytoval nikde v starých záznamoch (Prošek 1949), ani v novších sondách (Hromadová et al. v tlači). Celková stratigrafia spodnej a strednej časti sondy 1/2019 zodpovedá pomerom, ktoré opísal F. Prošek pre sondu I/1949, prípadne sondu II a III/1949, kde bola zafixovaná nasledovná stratigrafická situácia: „hnědošedá ornice, šedavě hnědá hlína, cicvárová spraš WIII“ (Prošek 1949), v strede ktorej leží kultúrna vrstva. Opis plne zodpovedá meniacej sa stratigrafickej situácii v sonde 1/2019. Vzhl'adom na šírku sond I, II a III pretínajúcich sprašový chrbát predpokladáme, že preložená, tri metre široká vrstva v spodnej časti sondy 1/2019 patrí zrejme pozostatkom starých sond II a III/1949 (obr. 2). Potvrdzuje to nielen jej stratigrafia, ale aj úplná absencia nálezov v tejto časti skúmanej sondy.

\section{Diskusia}

\subsection{Interpretácia objektu a antropogénnej vrstvy}

Antropogénna vrstva $v$ Podkovici bola objavená na príliš krátkom a úzkom úseku, aby bolo možné urobił jednoznačné závery, týkajúce sa planigrafie nálezov či mikrostratigrafie vrstiev. Charakter nálezov umožňuje predbežnú interpretáciu a ul'ahčuje d’alšie plánovanie výskumu. Na základe analýz predstavených v predmetnej štúdii predpokladáme priamy vztảah antropogénnej vrstvy k zahĺbenej štruktúre v jej začiatkoch, ktorá je zjavne jej súčastou. Ako už bolo spomenuté, na základe vertikálnej distribúcie nálezov vo vrchnej časti sondy, ich polohe, tafonómii a jednotného charakteru spraše možno predpokladat', že vrstva nie je až tak vel'mi poškodená ako v nižších častiach sondy a predstavuje tak perspektívne miesto pre rozšírenie výskumu.

Najvýznamnejším výstupom terénnych prác je nález evidentnej zahíbenej štruktúry vo vrchnej časti sondy, objektu 1. Jeho interpretácia a funkcia je i nad'alej predmetom diskusie. Problémom je nielen malý rozsah výskumu, ale predovšetkým súčasná úroveň poznatkov o podobných objektoch z moravianskeho sídliskového areálu a okolia. Základnou otázkou je, či je možné objekt interpretovat ako jamu, alebo ohnisko. Mikrostratigrafia vrstiev a distribúcia nálezov v zahíbenom objekte, ako aj diskusia k nálezom podobných objektov z iných paleolitických lokalít, nám dovol'uje urobit iba čiastočné závery, ktoré by mohli napomôct’ k jeho výslednej interpretácii.

Povrchová vrstva a okraje objektu 1 sčasti pravdepodobne chýbajú, hoci celkovo objekt nie je vel'mi rozvlečený do okolitých vrstiev. Povrchy jám, pokial' v minulosti neboli prekryté, bývajú vo všeobecnosti pomerne často poškodené alebo chýbajú, či už v dôsledku soliflukcie alebo zvolenej metodiky výskumu (Buločnikova 2007; Leonova, Gavrilov 2012; Sergin 1983). Ústie jám je zvyčajne v neporušených kultúrnych vrstvách užšie ako jeho niekdajšia šírka, čo je výsledkom postdepozičnej deštrukcie jamy (zvyčajne tlakom nadložných sedimentov či v prípade permafrostu v súvislosti s jeho opakovaným rozmŕzaním). Ústie objektu 1 je však misovité, široké a bolo porušené iba minimálne. Misovitá štruktúra iba mierne erodovala v smere dolu svahom. Proces deštrukcie povrchovej vrstvy mohol byt rýchly alebo objekt zasiahol minimálne.

Výplň objektu je tvorená centrálnou častou zo silne prepáleného popolovito-uhlíkového substrátu so zlomkami okru, kamennými nástrojmi a vel'kými kusmi kremenca a sl’udy. Okrajové časti objektu sa vyznačujú zmiešaným sedimentom s prímesou popola, zriedkavých kamenných nástrojov, okru a koncentráciami sl’udy. Dno a okraje typických jám z mladopaleolitických lokalít sú často pokryté zvrstveným sedimentom bez nálezov, čo sa prejavuje najmä v mikroprofiloch (Buločnikova 2007). Podobná situácia je aj v objekte na Podkovici. Okrajový sediment bez nálezov môže predstavovat pôvodné dno objektu 1.

Dná jám zahĺbených objektov sú dôležitým štruktúrnym prvkom, ked’že najlepšie reflektujú primárnu funkciu jamy. Práve tu sa najčastejšie zachovávajú zvyšky jej pôvodnej výplne (Sergin 1983, 27). Popolovitý sediment v objekte 1 zrejme predstavuje d’alšiu etapu zaplnenia, ktorej dominuje hlboká a masívna koncentrácia minerálno-organického substrátu s kremencami a prepálenými artefaktami v strede objektu. Z celkovej štruktúry usudzujeme, že prvá výplň jamy mohla byt’ odlišná a až po vyčistení sa do nej mohli dostat prepálené predmety, prípadne slúžila ako ohnisko. Primárnou otázkou, ktorá vzniká v súvislosti s týmto objektom je jeho funkcia, teda či ide o jamu, ohnisko in situ, prípadne kombináciu obidvoch, alebo sú sedimenty s prepálenými zvyškami nahromadené v jame sekundárne. Žial', obmedzené možnosti analýzy a súčasný stav sedimentov nám neumožňujú jednoznačne odpovedat na túto otázku.

Klasifikácia zahĺbených objektov je komplikovaná a v ideálnom prípade je dobré porovnat zahíbené objekty medzi sebou $\mathrm{v}$ rámci jednej vrstvy, prípadne na príbuzných lokalitách s vrstvami v sprašiach MIS2. Typy jám sa však môžu medzi jednotlivými lokalitami odlišovat. Ich výsledná forma je totiž výsledkom celého radu príznakov, závisiacich od formy reliéfu, sociokultúrnych aspektov, paleoklimatických podmienok pri konštrukcii zahíbenia (napr. stav pôdy, prítomnost̉ permafrostu a jeho roztápanie vo vrchných vrstvách), dížky osídlenia lokality či jej účelu. Pokial' ide o štruktúru osídlenia na skúmanej lokalite alebo na okolitých gravettienskych lokalitách v Moravanoch nad Váhom môžeme rekonštruovať niektoré predpokladané situácie.

Predpokladá sa, že sídliskové jamy v paleolite nie sú charakteristickým prejavom jednorazového krátkodobého osídlenia či tzv. kill-sites a nie sú ani typické pre súčasné etnograficky známe skupiny lovcov, zberačov (Binford 1983; Sergin 1983). Ich prítomnost' je teda vel'mi špecifickým sídelným prvkom a je zaujímavé, že práve na krátkodobo osídlených moravianskych lokalitách (podl’a Ambrož et al. 1952, 97; Hromada 1998 a pod.) sa vyskytujú jamy spolu s malými plytkými ohniskami. F. Prošek spomína na Podkovici ohnisko uprostred pol’a I (sektory 24-25). Detailný opis objektu z dôvodu chýbajúcej časti nálezovej správy z roku 1949, bohužial', nemáme k dispozícii, rovnako ani podrobnejšie nálezové okolnosti. Nálezová situácia je v denníku a rukopise opísaná F. Proškom, že ide „pravdepodobně o ohnište“ (Prošek 1949). Priestor je však silne poškodený hlbokou orbou, teda jeho presná interpretácia, rovnako ako v prípade objektu 1/2019, ostáva nejasná. Zaujímavé je, že nálezy hrotov s vrubom sa podl’a F. Prošeka vztahujú práve k tomuto objektu (dva boli nájdené „u zbytkư ohnište, třtetí ležel ve skupině nálezů s dentáliemi“; Prošek 1949). Kultúrna vrstva bola podl’a všetkého hrubá okolo $5 \mathrm{~cm}$ a zahŕňala drobné úlomky kostí, rozptýlené nástroje a dentáliá.

Na Lopate II bola počas výskumu nájdená jama v tesnej blízkosti ohniska a niekol'ko d’alších porušených popolovitých štruktúr. Planigrafia nálezov v okolí jamy a ohniska nereflektovala žiadnu konkrétnu štruktúru alebo špecializáciu a priestor obsahoval iba málo nástrojov (Kozłowski ed. 1998, 34). V celku A, na Lopate II, bolo nájdené väčšie plytké ohnisko s aspoň troma horizontami výplne (Kozlowski ed. 1998, 27). Ohnisko nemalo prepálený okraj, resp. podložný substrát a výplň je podl’a opisov autorov podobná výplni objektu 1 z Podkovice: hnedo-čierna výplň ohniska obsahovala šošovky popola 
zmiešaného s prepálenými kostami a uhlíkmi, zriedkavo minerálneho farbiva. Vnútri ohniska sa nachádzali aj prepálené kamene a hoci autori presne nešpecifikujú ktoré, väčšina prepálených neopracovaných kameňov z celku A patrí kvarcitu, arkózam, pieskovcu a vápencom miestneho pôvodu (Kozłowski ed. 1998, 34, 84). Ohnisko bolo poškodené v dôsledku erózie dolu svahom a stred pretínala l’adová trhlina s výplňou z mladších paleolitických vrstiev.

V sektoroch A2, A3, B2 a B3, v susedstve vel'kého ohniska, sa nachádzala asi $40 \mathrm{~cm}$ hlboká jama okrúhleho tvaru, s priemerom približne $70 \mathrm{~cm}$, pôvodne identifikovaná ako zásobnicová jama (Kozłowski ed. 1998, 28). Analýzou obsahu pozostávajúceho predovšetkým z fragmentov kostí (kosti a zuby soba, metakarpálne kosti medved’a hnedého, metapódium rosomáka, holenná a lýtková kost̉ mamutieho mlád’ata i jeho zub, pričom dno jamy vykrývali predovšetkým sobie elementy) sa dospelo k záveru, že spomínaná jama z Lopaty II je vel'mi podobná plytkým misovitým jamám strednodneprovského typu (Vlačiky 2012, 129). Typologicky ide skutočne o hlbšiu misovitú jamu, vel'mi pravdepodobne využívanú ako odpadový objekt, s koncentráciou pozostatkov spojených možno so spracovaním koží než uskladnenia mäsa. Takáto interpretácia dáva zmysel aj v kontexte celkovej dížky osídlenia lokality (Kozłowski ed. 1998, 128-130), kde dlhodobé skladovanie mäsa nie je logické. Ide o najhojnejšie sa vyskytujúci typ jám na mladopaleolitických lokalitách. Z dokumentácie, bohužial', nie je jasné, či je výplň jamy druhotná. Hoci je táto jama iba málo podobná objektu 1/2019 na Podkovici, v prípade akumulácie odpadu v tomto objekte zdiel'ajú tú istú funkciu.

Z Lopaty I chýbajú údaje z výskumu, avšak na jedinom zachovanom výskumnom pláne L. Zotza (Hromada 1998, 150, obr. 3) sa črtá tmavými farbami zvýraznený okrúhlo oválny objekt s výrazne farebne odlíšeným okolím oválneho tvaru. Objekt je približne 50-60 cm široký, oválna štruktúra v okolí pokrýva až 1,5 × 2,5 m. V širšom okolí objektu sa nenachádzajú takmer žiadne nálezy. Práve naopak, bohatá koncentrácia kostí a kamenných nástrojov je situovaná južne a východne od objektu, úplne oddelená sterilnou vrstvou, resp. akousi bariérou. Zachované fotografie ukazujú, že tím L. Zotza túto čast̉ začistil, priestor však ostal bez nálezov. V západnej časti hraničí s objektom malá koncentrácia kameňov a fragmentov kostí (vrátane časti sobieho parohu). Zo severnej a severovýchodnej časti je priestor objektu vyplnený nálezmi, a to predovšetkým čierno zafarbenými kameňmi. O výplni objektu nemáme žiadne informácie, na pláne nie je zakreslené nič. Podl’a plánu však zrejme existoval priečny západovýchodný profil celého objektu, vrátane oválnej štruktúry, čo znamená, že objekt bol pravdepodobne zahíbený na celú šírku, s koncentráciami kamenných a kostených nálezov okolo neho, čo by mohlo byṫ podobné ohnisku alebo jame s popolovitou výplňou.

O d'alších zahíbených objektoch na moravianskych gravettienskych sídliskách nemáme dostatočné množstvo údajov, rovnako ani z lokalít z trenčianskeho regiónu. Na starších gravettienskych lokalitách z okolia Pavlovských vrchov sa vyskytovalo celé spektrum jám $\mathrm{s}$ komplikovanou mikrostratigrafiou, ktorých podrobnejšiu analýzu komplikuje staršia dokumentácia. Z obdobia pavlovienu sú mimoriadne zaujímavé jamy a ohniská z ned’alekej rakúskej lokality Krems-Wachtberg, vynikajúco dokladajúce nielen vztahahy medzi vrstvou (Händel 2017; Händel et al. 2009), ale aj vztah medzi mikrostratigrafiou ohniska 1 a planigrafiou nálezov v okolitej kultúrnej vrstve (Thomas, Ziehaus 2014). Bohužial', tieto štruktúry sa tvorili v starších sprašiach a mierne odlišných klimatických podmienkach ako vrstvy na Podkovici. Poskytujú však celé spektrum porovnávacích možností. Zaujímavou je nielen otázka zachovalosti a formy jám pri erózii okolitých vrstiev, ale aj otázka chronológie jám na lokalite a dížky ich použitia. Napríklad priamo pod centrálnym ohniskom 1 sa nachádzala jama P3 (Händel et al. 2009, 190, Fig. 3), jeden z výnimočných príkladov kombinovaného objektu, ktorý v ruskej klasifikácii získal názov podohnisková jama (Gavrilov 2016, 82). V danom prípade išlo o ohnisko založené v plytkej jame, ktorá stratila pôvodnú funkciu. Stopy degradácie ústia jamy P3 boli viditel'né v profile a sú presným opakom ústia objektu 1 z Podkovice. Ďalšími jamami, úzko súvisiacimi s počiatočnými fázami použitia ohniska sú jamy P6 a P7. Všetky obsahovali zvyšky prepálených kostí, uhlíkov a neprepálené artefakty premiešané v hnedom substráte. Predstavujú sediment, ktorý bol zhrnutý do jám z ohniska počas jeho používania, resp. čistenia (Händel et al. 2009, 191). Podobná situácia by mohla byt zaujímavým vysvetlením výplne objektu 1/2019 na Podkovici, čo by zároveň teoreticky indikovalo blízky výskyt ohniska.

Z mladších moravských lokalít sú zaujímavostou štruktúrne a planigrafické vztahy medzi zahíbenými objektami a planigrafiou nálezov na lokalite v Petřkoviciach (Svoboda 2008). Výplň ohniska je pre tafonomické špecifiká identifikovatel'ná iba na základe prepálených kostí a prepálenej podložnej sprašovej vrstvy (Svoboda 2008, 40). Jamy a jamky sú v Petřkoviciach asociované s ohniskom (Svoboda 2008, 41), podobne ako na Lopate II, hoci sa morfologicky a funkčne odlišovali.

Predložené štúdie sú dôkazom, že dôslednou analýzou mikrostratigrafie a výplne jamy je možné v mnohých prípadoch relatívne podrobne rekonštruovat' etapy jej užívania, od jednorazového či viacrazového zaplnenia obsahom, cez deštrukciu a prípadnú rekonštrukciu jamy až po jej spustnutie (Buločnikova 2007, 179). Tento proces je dôležitý pre determináciu funkcie zahĺbeného objektu, ktorá však nemusí byt’ vždy jednoznačná. Práve to je prípad aj zahíbeného objektu 1/2019 z Podkovice, ktorého výskum a interpretácia vyžadujú d’alšie rozšírenie plochy, ako aj spektra využitých analýz. Popolovitá výplň, ojedinelé uhlíky a prepálené artefakty ešte zákonite nesvedčia o horení a využití zahíbenia ako ohniska, nakol'ko materiál mohol byt do objektu zhrnutý z iného miesta pri opakovanom či oportunistickom zaplnení jamy. Absencia stôp po prepálení stien nie je spol'ahlivým dôkazom, že nejde o ohnisko. Odpovede na otázky týkajúcej sa klasifikácie a funkcie môžu priniest’ pohl'ad na objekt v širšom kontexte kultúrnej vrstvy. Objekt 1 nie je vzhl'adom na skúmanú plochu preskúmaný v celom jeho rozsahu, a teda nepoznáme jeho reálne rozmery ani kontext. Spojitost’ s antropogénnou vrstvou je silne limitovaná jeho povrchovým poškodením. Po začistení plochy bolo dno objektu a vrstvy zakonzervované a ponechané na účely d'alšieho výskumu, ktorého hlavným cielom bude rozšírenie skúmanej plochy.

\subsection{Archeologické nálezy a chronokultúrne zaradenie lokality}

Chronologické zaradenie archeologických nálezov, či už na základe priameho datovania vzoriek z archeologickej vrstvy, analýzy chronologicky a kultúrne citlivých artefaktov, alebo geochronologické porovnanie vztahov medzi vrstvami na jednotlivých moravianskych lokalitách a profiloch je jednou z kl'účových otázok archeologického výskumu v Podkovici. Popri náraste počtu datovaní zo susedných a príbuzných lokalít (Wilczyński et al. 2020) a upresnení datovacích metód je táto otázka viac ako aktuálna. Bohužial', séria datovaní získaná z moravianskych lokalít (napr. Verpoorte 2002) je stále málopočetná či staršieho dáta.

F. Prošek zaradili spolu s kolegami lokalitu na Podkovici na základe vlastných geochronologických pozorovaní a dobovej znalosti o artefaktoch do Périgordienu V, podl'a chronológie 
D. Peyrony (Ambrož et al. 1952, 96), resp. „do pozdního aurignacienu čili gravettienu“ (Ambrož et al. 1952, 86). V dobovom ponímaní francúzskej chronológie by to patrilo k strednému až mladému gravettienu, $\mathrm{v}$ súčasnosti však korešponduje výlučne s mladým gravettienom. Na geochronologické zaradenie lokality sa sústredil aj tím, spracúvajúci materiál zo susednej Lopaty II (Pawlikowski et al. 1998). Koreláciou sprašových vrstiev s archeologickými údajmi M. Pawlikowski s J. Hromadom predpokladali staršie alebo približne rovnaké zaradenie vrstiev v Podkovici ako v Lopate II (Hromada 1998, 154; Pawlikowski et al. 1998, 585). Podl'a všetkého mohli vrstvy v polohe Podkovica ležat vo svetložltej karbonátovej spraši, podobnej ako v Lopate II. Archeologické vrstvy v polohe Lopata II, rozdelené na spodný a vrchný horizont, sa vzt̉ahujú k vrchným častiam tejto spraše (Pawlikowski et al. 1998, 575). Stojí za zmienku, že vo vrchných častiach tejto vrstvy boli identifikované aspoň dve generácie mrazových trhlín (Pawlikowski et al. 1998, 585), ktorú ju nateraz pomohli presnejšie geochronologicky zaradit do obdobia okolo 21 kyr BP (Pawlikowski et al. 1998, 585). Tieto údaje bude nutné upresnit', okrem iného, aj v Podkovici. Nález artefaktu $\mathrm{s}$ kryogénnymi poškodeniami v antropogénnej vrstve $\mathrm{v}$ sonde 1/2019 je zaujímavou indikáciou k preskúmaniu potenciálnych kryogénnych procesov vo vrstve. Na základe dokumentácie F. Prošeka na nich upozornil už J. Hromada (Hromada 1998, 154). Archeologické nálezy z Podkovice by sa tak mohli zaradit? do podobnej stratigrafickej pozície ako kultúrna vrstva na lokalite Lopata II. Na takéto chronologické zaradenie Podkovice by odkazovali aj staršie rádiokarbónové dáta, získané z vrstvy na lokalite Lopata II (Verpoorte 2002, 314) či podobná štruktúra kultúrnych vrstiev (charakteristika alebo výplň objektov).

Dôležitým indikátorom stále ostáva typologická a technologická charakteristika štiepanej kamennej industrie. Prebiehajúca revízia starších zbierok je komplikovaná ich málopočetnostou, ako aj absenciou niektorých dôležitých údajov o nálezovom kontexte. $\mathrm{V}$ súčasnosti je identifikovaných minimálne pät rôznych kolekcií z Podkovice, reflektujúcich aktivity jednotlivých zberatel'ov a výskumníkov (L. Zotz, F. Prošek, J. Bárta, O. Čepan, moderné zbery a výskumy). V rámci analýzy týchto súborov (s výnimkou zbierky O. Čepana; Kaminská, Kazior 2000) sme dospeli k typologickým záverom, ktoré sme zosumarizovali v nižšie uvedenom texte, s ciel'om poskytnút všeobecný prehl'ad o kamennej industrii z Podkovice a vytvorit tak diskusiu o nových avšak počtom výrazne limitovaných nálezov z výskumu z roku 2019 (84 kusov, tab. 1). Konkrétne typologické závery spolu s presnými štatistickými údajmi a mierami však budú súčastou pripravovanej publikácie (Klaric, Hromadová v príp.).

Medzi najviac používané suroviny na Podkovici patrí miestny rádiolarit a silicity z oblasti Pol'ska, pravdepodobne morénového alebo fluvio-glacigénneho pôvodu zo severných Karpát a z južného Pol’ska. Tento materiál bol použitý na štiepanie čepelí a čepiel'ok rôznej vel'kosti z jednopodstavových jadier. Najdlhšia čepel' z jednopodstavového jadra zo silicitu bola pravdepodobne importovaná, zatial' čo najmenšie čepiel'ky pochádzajú z rydlovitých jadier alebo jadier z malých blokov rádiolaritu, či silicitu (Klaric, Hromadová v príp.). Z typologického hl'adiska je pre sériu charakteristická prítomnoste rydiel rôzneho typu, retušovaných čepelí, niekedy s hrotitým ukončením, fragmentov mikrolitov s otupeným bokom a hrotov s vrubom. Morfologicky a technologicky možno variabilnú skupinu hrotov s vrubom rozdelit do dvoch kategórií, a to drobnejšie hroty s vrubom súvisiace zrejme s projektilmi a výrazne masívnejšie kusy, pravdepodobne slúžiace ako nože (Klaric, Hromadová v príp.). Práve tieto artefakty sú často porovnávané s hrotmi s vrubom známymi z kostenkovsko-avdejevskej kultúry (Grigoriev 1993). Hroty z Podkovice a zvlášť masívnejšie formy, nie sú v porovnaní napríklad s kostenkovskými analógiami retušované na ventrálnej strane. Ked’že hroty s vrubom kostenkovského typu v kolekciách z Podkovice identifikované neboli, nemožno sa zatial' stotožnit so všeobecne rozšírenou mienkou o východoeurópskom pôvode vplyvov pri formovaní týchto industrií (napr. Hromada 1998; Kozłowski ed. 1998). Z hl’adiska budúcej charakteristiky kolekcie z Podkovice môže zohrávat významnejšiu úlohu diverzita takých morfotypov ako rôzne mikrolitické formy s otupeným bokom, napr. čepiel'ky s otupeným bokom, mikrogravetty, čepiel'ky s otupeným bokom a retušovaným zakončením.

Na základe asociácie ženskej plastiky (venuše) a hrotov s vrubom je industria z Moravian nad Váhom-Podkovice často definovaná ako industria patriaca k tzv. horizontu hrotov s vrubom, prípadne ku kostenkovsko-willendorfskej kultúre (napr. Kozłowski 1969; 2008; Otte 1981), blízka k materiálu z vrstvy 9 vo Willendorfe II (Rakúsko) alebo lokality Kraków-Spadzista (Pol’sko; napr. Wilczyński et al. 2015). Reprezentuje tiež určité analógie k lokalite Hidasnémeti v Mad’arsku (Simán 1989). V európskom meradle však korešponduje predovšetkým s neskorou fázou gravettienu, čo je v súčasnosti aj jej najpresnejšie chronokultúrne zaradenie.

Bohužial', datovania získané z materiálov z Podkovice zatial' neumožňujú presnejšie chronologické zaradenia lokality. Komplikovanú situáciu so získaním vzoriek z poškodených vrstiev či kosteného materiálu s nízkym podielom kolagénu by mohlo vyriešit systematické štúdium geochronológie v moravianskom sídliskovom areáli, analýzou kompletnejších sprašových profilov spolu s použitím nekonvenčnejších datovacích metód, napr. ECG (Moine et al. 2017).

\subsection{Revízia starých výskumov}

Na základe slabo rozpoznatel'ného zásypu sondy 1/2016 sme dospeli k záveru, že nehlboké výkopy F. Prošeka nemusia byt viditel'né v profiloch, tým viac po 70. rokoch od výskumu. S podobným problémom sa mohol stretnút aj F. Prošek pri hl'adaní sond L. Zotza a K. Absolona v severnej časti sprašového chrbta. Tieto výkopy v rukopise označil nejednoznačne a podl'a neho „lokalizovat starší výzkumy bylo dosti obtižné a mohlo být provedeno pouze $v$ [nečit.]. U většiny výkopů jse podařilo určit jejich polohu avšak nemohla být zjištěna plocha výkopù." (Prošek 1949). Spomenutý text predstavuje jediný zdroj informácií, že s geologickým tímom a presnými údajmi o ich polohe si nebol istý ich identifikáciou. Možno k tomu prispela kultivácia pôdy (hlboká orba) či erózia spraší a ich stenčovanie na úkor humusového horizontu. Proškovu sondu predbežne predpokladáme v spodnej časti sondy 1/2019 a mohla by ju charakterizovat absencia ostrého prechodu medzi ornicou a sprašou, ako aj relatívne jednotná farebnosť výplne, prejavujúca sa hlavne v profiloch v híbke $35-37 \mathrm{~cm}$. Situácia bude priebežne overovaná v nasledujúcich výskumných sezónach.

\section{Záver}

Počas revízneho archeologického výskumu v Moravanoch nad Váhom-Podkovici boli získané dôležité nálezy a nálezové situácie, súvisiace so zvyškom kultúrnej vrstvy, silne narušenej pedologickými procesmi. Vzhl’adom na rozsah preskúmanej plochy, priestorová distribúcia artefaktov nevytvárala žiadnu viditel'nú štruktúru. Čast’ artefaktov vykazovala znaky mechanického posunu. Spomedzi nálezov možno spomenút fragment dentália, fragmenty sobích pozostatkov, štiepanú kamennú industriu, vrátane hrotu s vrubom. Významným je nález zahíbeného objektu, nakol'ko ide o prvý zahĺbený objekt tohto druhu na lokalite, potvrdený modernými výskumnými metódami. Objekt sa vzhl’adom na skúmanú plochu a limitované 
analógie nepodarilo s istotou klasifikovat'. Mohlo by íst’ o jamu alebo ohnisko, prípadne kombináciu obidvoch. Vzhl'adom na stav sedimentov a iba čiastočné preskúmanie objektu bude nutné nálezovú situáciu overit a rozšírit plochu výskumu smerom na juhozápad. Týmto smerom je orientovaná značná čast̉ nepreskúmaného objektu. Okrem iného, vrstva má smerom na juh podl'a údajov F. Prošeka z roku 1949 tendenciu prehlbovat sa, a tak sa otvára možnost dostat’ sa k neporušeným častiam kultúrnych vrstiev.

V rámci hl'adania sond a skúmaných plôch z výskumu v roku 1949 sa preukázali limitované možnosti použitia starej dokumentácie. Pôdny profil v sondách, ako aj sklon zodpovedajú stratigrafii sond I až III z výskumu z roku 1949. Erodovaný povrch sprašových vrstiev, ktorý sa prejavil v profiloch sond v stredných polohách sprašového chrbta potvrdzuje aj terénna dokumentácia F. Prošeka z roku 1949. V juhozápadnej časti sondy 1/2019 stratigrafia reflektuje narušenie pôdnych vrstiev do híbky aj $40 \mathrm{~cm}$, avšak stále nie je jasné, či sonda zachytila staré výkopy F. Prošeka. Vzhl'adom na komplikácie spojené s hl'adaním staršej sondy z roku 2016 a údajov z terénnej dokumentácie F. Proška je možné, že zásypy starých sond môžu byt' iba vel'mi slabo viditel'né v súčasných profiloch. Čiastočné vysvetlenie by mohli prinieste údaje z plánovaných hlbších geologických sond, v rámci ktorých by bolo možné stratigraficky porovnat určité časti lokality so staršími údajmi. Takéto sondy sú nutné aj pre geochronologické začlenenie lokality v kontexte širšieho okolia, porovnanie s profilmi napr. v Hlbokom a Vel'kom Jarku, či ich litostratigrafickú a paleopedologickú koreláciu s d’alšími sondami v širšom okolí. Vzhl'adom na to, že primárny ciel' výskumu, nájdenie či potvrdenie existencie archeologických vrstiev bol naplnený, hl'adanie starých sond bude ponechané ako čiastkový ciel' pri budúcom terénnom výskume.

\section{Pod'akovanie}

Príspevok vznikol s podporou projektov VEGA č. 2/0101/19 a APVV 16-0441. Za posúdenie kamennej suroviny d’akujeme M. Chebenovi (AÚ SAV, Nitra, Slovensko), za pomoc pri identifikácii mineralogického a chemického zloženia vrstvy a nálezov P. Konečnému (ŠGÚDŠ, Bratislava, Slovensko), za doplnkové informácie K. N. Gavrilovovi (Institut archeologii Russkoi akademii nauk, Moskva, Rusko), M. Händelovi (Institute for Oriental and European Archaeology OREA, Viedeň, Rakúsko) a laboratóriu Centre National de la Recherche Scientifique, UMR7055 (Francúzsko) za finančnú podporu terénneho výskumu. Zároveň srdečne d'akujeme kolegom z Moravského zemského muzea (Brno, Česká republika) za vzácne informácie $\mathrm{k}$ histórii moravianskych výskumov, ktoré významne napomohli v pátraní po materiáli.

\section{Literatúra}

Ambrož, V., Ložek, V., Prošek, F. 1952: Mladý pleistocén v okolí Moravan u Pieštan nad Váhom. Anthropozoikum 1 (1951), 53-142.

Bárta, J. 1965: Slovensko v staršej a strednej dobe kamennej. Bratislava: Vydavatel'stvo Slovenskej akadémie vied.

Bárta, J. 1970: Sídliská zo staršej doby kamennej na okolí Moravian nad Váhom. Almanach Balneologického múzea Piešt’any, 31-40.

Binford, L. R. 1981: Bones. Ancient men and modern myths. Studies in Archaeology. New York: Academic Press.

Binford, L. R. 1983: Pursuit of the Past. Decoding the Archaeological Record. London: Thames and Hudson.

Bronk Ramsey, C. 2021: OxCal [online]. In: Oxford Radiocarbon Accelerator Unit. Version 4.4 (current release). [cit. 2021-01-12]. Dostupné z: https://c14.arch.ox.ac.uk/oxcal.html\#program.

Buločnikova, J. V. 2007: Jamy novogo žilogo objekta Avdeevo. In: N. B. Leonova (ed.): Problemy archeologii kamennogo veka (k jubileju M. D. Gvozdover). Moskva: Dom jevrejskoj knigi, 170-188.
Dokládal, M. 1999: Morfologie spálených kostí. Význam pro identifikaci osob. Sborník prací Lékařské fakulty. Brno: Masarykova univerzita.

Fernández-Jalvo, Y., Andrews, P. 2016: Atlas of Taphonomic Identifications. Vertebrate Paleobiology and Paleoanthropology Series. Dodrecht: Springer.

Gavrilov, K. N. 2016: Verchnij paleolit bassejna Desny. Prejemstvennost' $i$ variabel'nost' v razvitii material'noj kul'tury. Moskva, Sankt Peterburg: Nestor-Istorija.

Grigoriev, G. 1993: The Kostenki-Avdeevo Archaeological Culture and the Willendorf-Pavlov-Kostenki-Avdevo Cultural Unity. In: O. Soffer, N. D. Praslov (eds.): From Kostenki to Clovis: Upper Paleolithic-Paleo-Indian adaptations. New York: Plenum Publishing, 51-65.

Händel, M. 2017: The stratigraphy of the Gravettian sites at Krems. Quartär 64, 129-155.

Händel, M., Simon, U., Einwögerer, T., Neugebauer-Maresch, Ch. 2009: New excavations at Krems Wachtberg - approaching a well-preserved Gravettian settlement site in the middle Danube region. Quartär 56, 187-196.

Hromada, J. 1997: Mladý Gravettien v severozápadnej časti Karpatskej kotliny a jeho vat'ahy $k$ nadkarpatským oblastiam. Rkp. kandidátskej dizertačnej práce. Uložené: knihovna Archeologického ústavu SAV, Nitra.

Hromada, J. 1998: Gravettienske sídliská v Moravanoch nad Váhom a ich miesto vo vývoji mladého paleolitu strednej Európy. Slovenská archeológia LXVI(2), 145-167.

Hromadová, B., Klaric, L., Nemergut, A. v tlači: Revízny archeologický výskum v Moravanoch nad Váhom-Podkovici. Archeologické výskumy a nálezy na Slovensku v roku 2016.

Hue, E. 1907: Musée ostéologique. Étude de la faune quaternaire. Ostéométrie des mammiféres. Paris: Schleicher.

Ivanička, J. (ed.) 2007: Geologická mapa Považského Inovca a jv. časti Trenčianskej kotliny. Bratislava: Štátny geologický ústav Dionýza Štúra.

Ivanička, J., Kohút, M. (red.) 2011: Vysvetlivky ku geologickej mape Považského Inovca a jv. časti Trenčianskej kotliny. Bratislava: Štátny geologický ústav Dionýza Štúra.

Kaminská, L'. 2014: Staré Slovensko 2. Paleolit a mezolit. Archaeologica Slovaca Monographiae. Bratislava: VEDA, vydavatel'stvo SAV.

Kaminská, L', Kazior, B. 2000: The Late Gravettian in O. Čepan's collections from the Moravany-Banka area. In: J. K. Kozłowski (ed.): Complex of Upper Palaeolithic sites near Moravany, Western Slovakia. Vol. III. Late Gravettian Shouldered Points Horizon Sites in the Moravany-Banka Area. Nitra: Archeologický ústav SAV, 31-72.

Kaminská, L', Nemergut, A., Žaár, O. 2011: Prieskum stredného Považia. Archeologické výskumy a nálezy na Slovensku v roku 2008, 122-124.

Klaric, L., Hromadová, B. 2016: Moravany-Podkovica debunked! Reassessment of an almost unknown «Willendorf-Kostienkian » collection of Western Slovakia. In: J. Wilczyński, P. Wojtal (eds.): 2nd Conference World of Gravettian Hunters. Kraków, Poland, 16-20 May 2016. Abstracts. Kraków: Instytut Systematyki i Evolucii Zwierąt Polskiej Akademii Nauk, 42-43.

Klaric, L., Hromadová, B. v príp.: Moravany-Podkovica debunked, reassessment of an almost unknown Willendorf-Kostenki collection of Western Slovakia.

Kozłowski, J. K. 1969: Problem tzw. kultury Kostienkowsko-Willendorfskiej. I. Analiza inwentarzy kamiennych. Archeologia Polski XIV(1), 19-85.

Kozłowski, J. K. 2008: The shouldered point horizon and the impact of LGM on human settlement distribution in Europe. In: J. Svoboda (ed.): Petřkovice. On shouldered Points and Female Figurines. Dolnověstonické studie 15. Brno: Archeologický ústav AV ČR, Brno, 181-192. 
Kozlowski, J. K. (ed.) 1998: Complex of Upper Palaeolithic sites near Moravany, Western Slovakia. Vol. II. Moravany-Lopata 2. (Excavations 1993-1996). Krakov: Jagellonian University, Institute of Archaeology.

Leonova, N. B., Gavrilov, K. N. 2012: Metodika issledovanij kul'turnych slojev kamennovo veka na stojankach otkrytovo tipa. In: N. B. Leonova, A. A. Maslennikov, K. N. Gavrilov (eds.): Issledovanije pamjatnikov epochi paleolita. Metodika polevych archeologičeskich issledovanij 7. Moskva: IA RAN, 6-27.

Lipecki, G., Wojtal, P. 1998: Mammal remains. In: J. K. Kozłowski (ed.): Complex of Upper Palaeolithic sites near Moravany, Western Slovakia. Vol. II. Moravany-Lopata 2. (Excavations 1993-1996). Krakov: Jagellonian University, Institute of Archaeology, 103-126.

Lyman, R. L. 2008: Quantitative Paleozoology. New York: Cambridge University Press.

Moine, O., Antoine, P., Hatté, C., Landais, A., Mathieu, J., Prud'homme, C., Rousseau, D. D. 2017: The Impact of Last Glacial climate variability in west-European loess revealed by radiocarbon dating of fossil earthworm granules. Proceedings of the National Academy of Sciences of the United States of America 114(24), 6209-6214.

Nemergut, A. 2010: Paleolitické osídlenie v Moravanoch nad Váhom-Dlhej. Výsledky výskumov Juraja Bártu z rokov 1963 a 1990. Slovenská archeológia LVIII(2), 183-206.

Nerudová, Z., Valoch, K. 2009: Moravany nad Váhom. Katalog paleolitických industrií z výzkumu prof. Karla Absolona. Anthropos 28, N. S. 20. Brno: Moravské zemské muzeum.

Otte, M. 1981: Le Gravettien en Europe centrale. Dissertationes Archaeologicae Gandenses 20. Bruges: De Tempel.

Pawlikowski, M., Alexandrowicz, W., Bánesz, L., Hromada, J., Kozłowski, J. K., Sobczyk, K., Kazior, B. 1998: Correlation between Loess Profiles on the Basis of Mineralogical, Malacological, and Anthropogenic Indicators: a Case Study from Moravany-Lopata, Western Slovakia. Geoarchaeology: An International Journal 13(6), 565-594.

Prat, F. 1987: Podstawy oznaczania szczatków ważniejszych ssaków Plejstoceńskich. Cz. II - tablice. Krakov: Uniwersytet Jagielloński, Kraków.

Prošek, F. 1949: Výzkum paleolitické stanice v Moravanech n. Váhem v roku 1949. Výskumná dokumentácia. Uložené: Oddelenie dokumentácie, Archeologický ústav SAV, Nitra.

Prošek, F. 1953: Problémy paleolitu Karpatské Kotliny. Rkp. referátu predneseného na konferencii v Košiciach. Uložené: knižnica Archeologického ústavu SAV, Nitra.

Reimer, P., Austin, W., Bard, E., Bayliss, A., Blackwell, P., Bronk Ramsey, C., Butzin, M., Cheng, H., Edwards, R., Friedrich, M., Grootes, P., Guilderson, T., Hajdas, I., Heaton, T., Hogg, A., Hughen, K., Kromer, B., Manning, S., Muscheler, R., Palmer, J., Pearson, C., van der Plicht, J., Reimer, R., Richards, D., Scott, E., Southon, J., Turney, C., Wacker, L., Adolphi, F., Büntgen, U., Capano, M., Fahrni, S., Fogtmann-Schulz, A., Friedrich, R., Köhler, P., Kudsk, S., Miyake, F., Olsen, J., Reinig, F., Sakamoto, M., Sookdeo, A., Talamo, S. 2020: The IntCal20 Northern Hemisphere radiocarbon age calibration curve (0-55 cal kBP) [online]. Radiocarbon 62 (4), 725-757. [cit. 2021-05-27]. Dostupné z: https://doi.org/10.1017/RDC.2020.41.

Sergin, V. Ya. 1983: Naznačenie bol’šich jam na paleolitičeskich poselenijach. Kratkije soobščenija 173. Kamennyj vek, 23-31.

Schmid, E. 1972: Atlas of Animal Bones. Amsterdam: Elsevier Publishing Company.

Simán, K. 1989: Hidasnémeti, Upper Palaeolithic site in the Hernád-valley (Northeast Hungary). Acta Archaeologica Carptathica XXVIII, 5-24.
Svoboda, J. 2008: Formation of the archaeological layers, structure of the site and features. In: J. Svoboda (ed.): Petřkovice. On shouldered points and female figurines. Dolnověstonické studie 15. Brno: Archeologický ústav AV ČR, Brno, 31-45.

Thomas, R., Ziehaus, J. 2014: Spatial and chronological patterns of the lithics of hearth 1 at the Gravettian site Krems-Wachtberg. Quaternary International 351, 134-145.

Verpoorte, A. 2002: Radiocarbon dating the Upper Palaeolithic of Slovakia: Results, problems and prospects. Archäologisches Korrespondenzblatt 32(3), 311-325.

Vlačiky, M. 2012: Intencionálna fragmentarizácia kostí v paleolitických kultúrach [online]. Rkp. dizertačnej práce. Masarykova univerzita. Přírodovědecká fakulta. Ústav geologických věd. Uložené: Archiv závěrečných prací Masarykovy univerzity [cit. 2021-05-19]. Dostupné z: https://is.muni.cz/th/j4yh9/.

Wilczyński, J., Goslar, T., Wojtal, P., Oliva, M., Göhlich, U., Antl-Weiser, W., Šída, P., Verpoorte, A., Lengyel, G. 2020: New Radiocarbon Dates for the Late Gravettian in Eastern Central Europe. Radiocarbon 62(1), 243-259.

Wilczyński, J., Wojtal, P., Sobieraj, D., Sobczyk, C. 2015: Kraków Spadzista trench C2: New research and interpretations of Gravettian settlement. Quaternary International 359-360, 96-113.

Wojtal, P. 2007: Zooarchaeological studies of the Late Pleistocene sites in Poland. Kraków: Polish Academy of Sciences, Institute of Systematics and Evolution of Animals.

Zotz, L. 1968: Die Venusstatuette von Moravany nad Váhom. Slovenská archeológia XVI(1), 5-14.

Zotz, L., Vlk, V. 1939: Das Paläolithikum des unteren Waagtales. Quartär 2, 65-101.

Žaár, O., Blašková, L., Vlačiky, M. 2016: Povrchové prieskumy na dolnom Považí. Archeologické výskumy a nálezy na Slovensku v roku 2011, 207-210, 317-319.

Žaár, O., Vlačiky, M., Moravcová, M. 2015: Povrchový prieskum paleolitických lokalít v okolí Pieštan. Archeologické výskumy a nálezy na Slovensku v roku 2010, 252-253, 358.

\section{Summary}

Archaeological research at the Moravany-Podkovica Paleolithic site began in the 1930s and diverse fieldworks and surface surveys were conducted by famous Prehistorians such as L. Zotz and $\mathrm{K}$. Absolon. However, the first systematic interdisciplinary research at the site only took place one decade later (1949) under the influence of F. Prošek, a young Czech specialist. Prošek's team excavated a large $300 \mathrm{~m}^{2}$ area, which revealed cultural layers and an impressive several meter high loessic stratigraphy. A significant number of artefacts and samples were gathered during this excavation. Among other research outcomes, it is worth insisting on the record of the stratigraphy of loess sediments, in which Paleolithic human occupation has been identified. However, the most significant find is the torso of the female figurine known as the "Venus of Moravany", which was accidentally discovered after agricultural ploughing in the early 1930s by a local farmer.

Despite the efforts of Prošek's successors to continue this work, no other fieldwork involving stratigraphic excavation was made before 2016. To estimate the field situation, three new trial trenches were dug between 2016 and 2019 under the direction of A. Nemergut and B. Hromadová.

The aim of this new field research in Podkovica was to locate Prošek's fieldwork, detect the old excavated area and assess if an intact cultural layer in situ still exists, as the site is considered to be largely destroyed and exhausted by decades of uncontrolled amateur surface collecting. The final goal of this preliminary work is to locate a preserved part and, if possible, to enlarge the trenches and conduct a proper excavation from 
a Paleoethnographic perspective. In 2019, the excavation of a $20 \mathrm{~m}$ long trench situated in the south-west of the previously excavated area was of utmost importance. During this work, an anthropogenic layer (close to the surface) with scattered lithic artefacts and faunal remains was identified. Nevertheless, the most significant discovery is an evident structure resembling a "shallow pit" with an artificial filling of burnt materials. This filling consists of a patchy matrix of ashes and loessic sediments and contains lithic artefacts, pieces of bones, burned stones, charcoals and small pieces of mineral dyes. Therefore, this is the first evident anthropogenic "structure" described at the site and confirmed by modern research methods. Others may have existed but remained undetected due to the rather crude method of excavations from the previous century. Unfortunately, due to the reduced width of the excavated trench (only $50 \mathrm{~cm}$ ) and the limited analogies available in the regional Paleolithic context, this structure has not yet been appropriately classified and further research is necessary. It could be a pit or hearth, or a combination of both. On the other hand, the filling of the feature provided several samples of a different nature, including bone, charcoals and burned minerals. Some can be dated or sampled for the mineralogical and chemical analysis (to explain the function of the feature).

The result of the first bone charcoal dated using the C14 method corresponds to a post LGM date (Graph 2, $17160 \pm 690$ and $20299 \pm 420$ uncal BP). Even if this result of the Paleolithic age is not in agreement with previous radiocarbon dates made on mammoth bones (from surface collecting; Graph 2, $22200 \pm 220$ and $22680 \pm 400$ uncal BP) and the classical typo-chronological attribution of the site (usually considered to be pre or sub-contemporary to LGM), it is still encouraging and demonstrates the great potential of this discovery. If these new dates obtained do not help to refine the chronology of the site, a more detailed study of the stratigraphy should be carried out since it is now possible to date loessic levels much more precisely (e.g. by radiocarbon dating on fossil earthworm granules; Moine et al. 2017). This would help to more accurately characterise the chronology of the human occupation at Podkovica and the entire loessic sequence of the Moravany area.

Unfortunately, our first trenches did not fully confirm the location of F. Prošek's excavated areas. We assume that the problem with identifying the old structures in the modern trenches can be associated with the lack of geolocation details in the old documentation and with the specificities of the sediments where 70-year-old trenches may only be barely visible in the current profiles.

During the excavations, a small collection of archaeological remains was gathered, including several dozen lithic artefacts and faunal remains. A few typical types of tools made from radiolarite and patinated exogenous flint can be identified: a shouldered point (comparable to the specimens published by Prošek), a couple of small retouched blades, fragments of burins and an abruptly backed bladelet fragment. Although this collection is limited, the tools identified correspond to the typological features of collections known from older excavations (Prošek, Zotz, Absolon) and surface collecting. The pooling of these collections has already enabled us to propose preliminary typological observations related to the site (Klaric, Hromadová 2016).

The two most exploited materials at the Podkovica site are local radiolarite and white patinated allochthonous flints. These materials have been exploited in a preferential unipolar way for the production of blades and bladelets of various sizes. From a typological point of view, the series is characterised by the presence of various types of burins, retouched and sometimes pointed blades, abrupt-backed microlithic and shouldered points of two distinct modules (light projectile points and more robust artefacts that are probably knives). These artefacts are often compared to the shouldered points of the Kostenki-Avdeevo Culture but in Podkovica, the points are not retouched on the ventral surface (unlike most of the Russian artefacts). Contrary to what is sometimes stated, we have not formally identified Kostenki knives in the different collections that were examined. Finally, a few microlithic backed elements show some diversity (backed bladelets, microgravettes and truncated backed bladelets).

The faunal remains from the 2019 trench are from various species: reindeer, hare and mammoth, which are typical of local biota and correspond to the climatic conditions and development of the local environment during LGM. Reindeer remains are also largely represented at neighbouring sites (such as Moravany Lopata).

With its "Venus" and the shouldered points, the Moravany Podkovica site is classically attributed to the Shouldered-Points Horizon or Willendorf-Kostenkian and is alleged to be close to layer 9 of Willendorf 2 (Austria) and the Krakow-Spadzista site. It also presents some analogies with the Hidasnémeti site in Hungary. On the European scale, these occupations appear to correspond to a rather late phase of the Gravettian. The loess stratigraphy, and the previous C14 dating, preliminarily dated it to the period before or around the LGM. Unfortunately, the new C14 dates obtained on samples from Podkovica do not allow a more accurate chrono-cultural classification of the site. It is necessary to continue fieldwork to enlarge the currently explored area and run a systematic study of the geochronology and loessic profiles of the region.

Therefore, in the future, we plan to replace the site within its wider environment. This work will include lithostratigraphic and paleopedological correlation of the Podkovica layers with large loessic profiles in Hlboký or Vel'ký Jarek (Moravany nad Váhom district) or those in the regional area.

\section{Kontakty}

Bibiána Hromadová

CNRS - UMR 7055 Préhistoire et technologie, MAE, 21 allée de l'Université

FR-92023 Nanterre

bibiana.hromadova@gmail.com

\section{Adrián Nemergut}

Archeologický ústav SAV

Akademická 2

SK-949 21 Nitra

adrian.nemergut@savba.sk

\section{Laurent Klaric}

CNRS - UMR 7055 Préhistoire et technologie, MAE, 21 allée de l'Université

FR-92023 Nanterre

laurent.klaric@cnrs.fr

\section{Martina Moravcová Ábelová}

Štátny geologický ústav Dionýza Štúra

Mlynská dolina 1

SK-817 04 Bratislava 11

martina.moravcova@geology.sk

\section{Martin Vlačiky}

Bellova 52

SK-831 01, Bratislava

martin.vlaciky@gmail.com 